\title{
Like Godfather, Like Son: Explaining the Intergenerational Nature of Crime"
}

\author{
October 19, 2009 \\ Randi Hjalmarsson ${ }^{\dagger}$ \\ University of Maryland \\ Matthew J. Lindquist ${ }^{\dagger \dagger}$ \\ Stockholm University
}

\begin{abstract}
This paper studies intergenerational correlations in crime between fathers and their children and the underlying mechanisms that give rise to these correlations. Using data from the Stockholm Birth Cohort, we find strong evidence of an intergenerational criminal relationship. Sons whose fathers have at least one sentence have 2.06 times higher odds of having a criminal conviction than sons whose fathers do not have any sentence. At the intensive margin, one additional sentence of the father increases the expected number of sons' convictions by 32 percent. Fatherdaughter relationships are generally not significantly different than fathers-son relationships. Traditional regression techniques indicate that socioeconomic status accounts for roughly onethird of the extensive margin father-son relationship and somewhat less, particularly at the intensive margin, for daughters. Over and above this, for both sons and daughters, our ability proxies account for an additional 20 percent. Finally, household heterogeneity, the most important component of which is household instability, accounts for almost one-third of the intergenerational relationships. More direct evidence regarding whether the intergenerational correlations arise through either an inherited traits mechanism or a father as role model mechanism is provided in four alternative experiments. These experiments focus on: (i) a sample of twins, (ii) an adoptee sample, (iii) the timing of the father's crime, and (iv) the quality of the father - child relationship. We find evidence that both direct channels play a role in the reproduction of crime from one generation to the next. Finally, we find that paternal incarceration may actually lower the number of crimes committed by some children, providing additional evidence of the importance of a behavioral transference mechanism.

Keywords: crime, illegal behavior, intergenerational crime, intergenerational mobility, risky behavior.

JEL codes: J62, K42.
\end{abstract}

\footnotetext{
* The authors would like to thank Anders Björklund, Eve Caroli, Kerstin Nelander, Matti Sarvimäki, Jerzy Sarnecki, Sten-Åke Stenberg and seminar participants at Essex University, the Empirics of Crime and Deterrence workshop, European Economic Association, Gothenburg University, Helsinki Center of Economic Research, IZA, Queen Mary University, Royal Holloway University, Society of Labor Economists, Stockholm University, Swedish Institute for Social Research, Yale Law School, Universidad Pablo de Olavide, University of Maryland Baltimore County, and University of Maryland College Park for their valuable comments and suggestions. We gratefully acknowledge financial support from the National Science Foundation (grant SES-0819032).

${ }^{\dagger}$ Contact address for Randi Hjalmarsson: 4131 Van Munching Hall, University of Maryland, School of Public Policy, College Park, Maryland 20742, Office Phone: 301-405-4390, Cell: 203-435-2954, Fax: 301-403-4675, and Email: rhjalmar@umd.edu.

\# Contact address for Matthew J. Lindquist: Department of Economics, Stockholm University, SE-106 91 Stockholm, Sweden, Phone: 46+8+163831, Fax: 46+8+159482, and Email: Matthew.Lindquist@ ne.su.se.
} 


\section{Introduction}

Crime runs in the family. Though this statement may elicit thoughts of the stereotypes depicted in movies like The Godfather or television series like The Sopranos, this stylized fact actually has a long history in criminology. ${ }^{1}$ There is also substantial anecdotal evidence of the familial nature of crime. For example, The New York Times published an article entitled, "Father Steals Best: Crime in an American Family" (Fox Butterfield, August 21, 2002) about a family of criminals in Oregon. Butterfield's article describes how the Bogle family patriarch, Dale Vincent "Rooster" Bogle, taught his children to steal, so that by age 10 his sons were already breaking into liquor stores or stealing tractor-trailer trucks. His daughters turned to petty crimes in order to support their drug addictions. By the time of his death in 1998, 28 of the Bogle clan had been convicted of crimes, including several of Rooster's grandchildren. Tracey Bogle, the youngest of Rooster's sons, is quoted as saying, "Rooster raised us to be outlaws...There is a domino effect in a family like ours... What you're raised with, you grow to become. You don't escape."

Although the Bogle family may be an extreme example (and the Corleone and Soprano families purely fictitious), U.S. Justice Department figures (cited by Butterfield) show that 47 percent of inmates in state prisons have parents or other close relatives who have also been incarcerated. The cost of ignoring this family cycle of criminality may be huge. Butterfield cites an official of the Oregon Department of Corrections who estimated the cost of incarcerating just five of the convicted Bogle family members at nearly three million dollars (in 2002 prices). And, this may just be a lower bound given that it neither accounts for the many administrative costs of their trials, probation, or paroles nor the costs born by the victims of their crimes.

\footnotetext{
${ }^{1}$ See Rowe and Farrington (1997) and the historical references therein.
} 
It is, therefore, surprising that the economics of crime literature has, as a rule, largely ignored the relationship between an individual's own criminality and that of his parents. ${ }^{2}$ Notable exceptions to this rule include Case and Katz (1991), Williams and Sickles (2002), and Duncan et al. (2005). For instance, using the 1979 National Longitudinal Survey of Youth and the Children of the National Longitudinal Survey of Youth, Duncan et al. (2005) report intergenerational correlations between mothers and their children for 17 behaviors and attitudes (both good and bad) measured during adolescence. They find striking support of the hypothesis that "likes beget likes" and, with regards to criminality, that daughters whose mothers were ever convicted are more than five times as likely to be convicted of a crime themselves. ${ }^{3}$

A number of important works that study intergenerational criminality have also been produced by criminologists and sociologists. This literature dates back to the seminal work of Glueck and Glueck (1950), who consider a sample of 1,000 American boys, half of whom are identified as delinquents; they find that 66 percent of delinquents had a criminal father while just 32 percent of non-delinquents had a criminal father. Additional evidence of an intergenerational criminal relationship has been found across multiple data sets, cities, and countries. ${ }^{4}$

\footnotetext{
${ }^{2}$ Rather, when studying the determinants of crime, economists tend to emphasize those factors illuminated in Becker's (1968) economic model of crime, e.g. the probability and severity of punishment as well as the returns to legitimate employment.

${ }^{3}$ Using data from the Boston Inner City Youth Survey, Case and Katz (1991) find that children with a family member in jail are eight percentage points more likely to report committing a crime in the last year. Using the 1958 Philadelphia Birth Cohort Study, Williams and Sickles (2002) find that 15 percent of criminals report having a father who was arrested during the respondent's childhood while just six percent of non-criminals report that their father was arrested.

${ }^{4}$ Several British studies (Ferguson, 1952; Wilson, 1987; and Farrington and West, 1990) also find that an individual's criminality is related to that of his family members. Using the Cambridge Study on Delinquent Development, Farrington and West (1990) find that 75 percent of a sample of dual conviction couples produced offspring who were also convicted. Gregory (2004) reviews some of these studies as well as others that consider the relationship between individual criminality and non-crime family characteristics. Using the Stockholm Birth Cohort (SBC), Janson (1982) finds that 9.8 percent of the boys with fathers that have no criminal record are delinquent while 19.9 percent of the boys with criminal fathers are delinquent. This positive correlation exists even within different social classes. More recently, using the SBC data, Murray et al. (2007) find that parental incarceration has no effect on children's offending, over and above parental criminality. The Rochester Youth Development Study is another ongoing, long-tem project that has produced considerable information concerning intergenerational links in anti-social behavior (see Thornberry 2009 for a nice overview and for references to relevant articles produced in this
} 
Current research on intergenerational criminality is concerned not only with documenting these relationships, but also with deepening our understanding of the sources of these correlations. The hope is that a better understanding of the underlying mechanisms, and of their relative importance, may help us to think more clearly about the effect of policies on criminal behavior. One important question is whether or not the parent - offspring correlation in crime is simply due to the existence of some common external factor, such as poverty, or whether there is a mechanism that directly links parent criminality to child criminality. If the former is true, then policies aimed at reducing poverty may also reduce crime. But, what if the observed intergenerational criminal correlations are produced by a behavioral model, such as a role model hypothesis in which the children directly observe and model their parents' behavior? If this is the case, then policies that appear to be successful at reducing crime today may reduce crime even further in the future. And, research that evaluates these policies and the resulting savings to society may underestimate their effectiveness by not taking into account the effect on future generations. For instance, researchers have found evidence that increasing the number of police deters crime; estimates of the elasticity of crime with respect to the number of police depend on the type of crime studied, but tend to be around -0.40 (Marvell and Moody, 1996; Corman and Mocan, 2000; Levitt, 2002). But, if children observe their parents abstaining from criminal behavior (as a result of this increased police presence) and subsequently decide to abstain from crime themselves, then these estimates may just be a lower bound on the deterrence effect of police.

Duncan et. al's (2005) study is one of several that consider the underlying mechanisms. Specifically, they conduct indirect tests of four potential sources of these relationships and find

project). Other recent studies on intergenerational crime include Farrington et al. (2009) and van de Rakt et al. (2009), both published in a special issue of the Journal of Criminal behavior and Mental Health concerning the intergenerational transmission of anti-social behavior. 
little evidence that they can be attributed to socioeconomic status or parenting style, but find some indirect evidence in support of both genetics and the role model hypothesis. Their work, however, is limited in the scope with which it can study intergenerational criminality since: (i) they only have data on juvenile, and not adult, criminality, (ii) they only have maternal crime data, and (iii) they cannot look at crime or sentence type. Most other studies have limitations due to small sample sizes, unrepresentative samples and/or self reported crime data. On the other hand, the few European studies that have access to large samples using criminal register data lack the necessary information concerning individual, family and neighborhood characteristics that are needed to explore the mechanisms driving familial similarities in criminal behavior.

This paper addresses these gaps by taking advantage of a Swedish dataset, the Stockholm Birth Cohort Study (SBC), which contains administrative crime records for both a cohort of more than 15,000 individuals born in 1953 (and residing in Stockholm in 1963) and their fathers. Due to the combination of a relatively large sample size, detailed criminal and non-criminal measures, as well as a long time horizon, this Swedish data set provides a unique opportunity to study intergenerational criminal correlations and the underlying mechanisms.

Our study is carried out in four stages. First, we document the existence of significant intergenerational correlations in criminal outcomes. In particular, we look at a father's sentencing record and correlate it with his son's or daughter's criminal record at both the extensive (i.e. any crime) and intensive (i.e. number of crimes) margins; the vast majority of previous research has been limited to looking at the extensive margin. We find that sons whose fathers have at least one sentence have 2.06 times higher odds of having at least one criminal conviction than sons whose fathers do not have any sentence and, at the intensive margin, each additional sentence of the father increases the expected number of sons' convictions by 32 
percent. The father-daughter intergenerational relationships generally do not significantly differ from those for the sons.

In the second stage, we regress measures of cohort member criminality on measures of paternal criminality and add in vectors of controls, which proxy for the underlying mechanisms, in a stepwise fashion. The aim of these regressions is not to make any statements of causality, but, rather, to see how much of the intergenerational relationship is accounted for by each set of controls. We find that social background accounts for roughly one-third of the father-son intergenerational criminal relationship and somewhat less, particularly at the intensive margin, for daughters. Over and above this, for both sons and daughters, our ability proxies account for an additional 20 percent. Finally, household heterogeneity, the most important component of which is household instability, accounts for almost one-third of the intergenerational relationships.

The third stage of the analysis presents more direct evidence of a causal link between fathers' criminality and that of their children by running a series of alternative experiments. Our experiments focus on: (i) the sample of twin pairs in our data as well as knowledge about their zygosity, (ii) adopted children, (iii) the timing of the father's crime, and (iv) the quality of the father - child relationship. Through these experiments, we consider two direct channels: (i) inherited traits and (ii) the father as a role model. We find evidence that both of these direct channels play a role in the reproduction of crime from one generation to the next.

Finally, we consider how the intervention of paternal incarceration affects child criminality. We actually find some evidence suggesting that paternal incarceration may offset the effect of having a criminal father; i.e. over and above the effect of father criminality, paternal incarceration may decrease the criminality of the child. However, it is difficult to rule out other 
potential explanations for this relationship, such as the possibility that incarcerated fathers were also not present in the household prior to incarceration.

The remainder of this paper is organized as follows. Section 2 describes the data and Section 3 presents the raw intergenerational criminal correlations. Sections 4 and 5 present the second and third stages of the analysis described above. In Section 6, we study whether there is a paternal incarceration effect. Section 7 summarizes our results and discusses their generalizability and policy implications.

\section{Data}

Crime Rates in Sweden, Europe and the U.S.

Before presenting our data, we must first put one popular misconception to rest. Sweden is not a country free from crime. A recent victimization study conducted by the EU ICS (2005, p. 97) concluded that: "In the EU context the level of crime in Sweden is medium high. Exposure to drugs-related problems is relatively rare. The prevalence of hate crimes is just above the EU mean." Official crime statistics for murder and motor vehicle thefts, arguably the two best documented and most comparable crimes across countries, are presented in Table 1. While murder is fairly rare in Sweden, motor vehicle theft is extremely common; in fact, the motor vehicle theft rate tends (in most years) to be higher in Sweden than in the United States and is well above the European average.

If we look at the historical trend in the total number of offenses reported (see Table 1), we see that our cohort of sons (born in 1953) faced an environment in which reported crime was three to four times higher than the environment that their fathers grew up in. This increase in 
reported crime is reflected in our data by the fact that only 12 percent of our fathers have a criminal conviction, while 33 percent of our sons have at least one criminal conviction. ${ }^{5}$

\section{Description of the Data Set}

The data set used in this paper is the Stockholm Birth Cohort Study (SBC), which is a database that was created in 2004 by matching two data sets. ${ }^{6}$ The first data set, the Stockholm Metropolitan Study (SMS), consists of all children born in 1953 and living in the Stockholm Metropolitan area on November 1, 1963. Data was collected from multiple sources, including individual and family surveys as well as administrative records; thus, this data set contains a rich set of variables concerning individual, family, social, and neighborhood characteristics. The SMS data was matched to The Swedish Work and Mortality Database (WMD), which consists of income, work, unemployment, in-patient, and mortality data for all individuals living in Sweden in 1980 or 1990 and who were born before 1985.

The work in this paper is based on data originating from the Stockholm Metropolitan Study, which consists of 15,117 individuals: 7,719 men and 7,398 women. The most important feature of this data is that it contains crime records of both the birth cohort and their fathers. For the birth cohort, we have measures of criminality for two time periods. Data for when the individual is below the age of 18 is primarily sourced from the child welfare committees

\footnotetext{
${ }^{5}$ We can not address the underlying causes of this increase in reported crime in this paper. The regression results described later in the paper, however, are completely robust to controlling for the birth year of the father, i.e. controlling for these generational effects.

${ }^{6}$ Carl-Gunnar Janson and Sten-Åke Stenberg managed and provided the original cohort data, Denny Vågerö organised the follow-up data and Reidar Österman managed the probability matching of the two data sets. Preparing data from the Stockholm Birth Cohort Study is an ongoing collaborative effort by the Swedish Institute for Social Research and by Centre for Health Equity Studies, partly financed by the Swedish Research Council. For a complete description of the project see Stenberg and Vågerö (2006) and Stenberg et al. (2007). Codebooks describing all of the data in more detail are available at http://www.stockholmbirthcohort.su.se/.
} 
(CWC). ${ }^{7}$ Records from the CWC are not available, however, for individuals who have moved out of the Stockholm area by this time; approximately 950 individuals moved out of the Stockholm area between the ages of 13 and 18. For individuals who remained in the area, we can identify whether a cohort member committed a delinquent act that resulted in an intervention by the CWC. We can also identify the general category of delinquent behavior: stealing, violent crimes, alcohol abuse or narcotics, and other offenses.

As the birth cohort ages into adulthood, crime data is obtained from the official police registrar (person- och belastningsregister, $P B R$ ). ${ }^{8}$ This registrar contains records of offenses that lead to an official report to the CWC or to a conviction. These crime data are divided into seven crime categories, including: violent crime or crimes against persons, stealing, fraud, vandalism, traffic crimes (that lead to a court conviction, e.g., driving without a license or under the influence of alcohol), narcotic crimes, and other crimes. For each year from 1966 to the first half of 1984 (i.e. when the respondents are age 13 through 31), we have information on the number of offenses in each of these crime categories as well as the sentence that was received; the 1966 data is actually a summary of all known crimes reported up to and including 1966.

\footnotetext{
${ }^{7}$ As in the United States, juveniles in Sweden are not subject to the same punishments as adults and are not processed by the same authorities.

${ }^{8}$ Since the PBR is a national register, we do not lose cohort members that move out of the Stockholm metropolitan area.
} 
The fathers' crime data also comes from the official police registrar. ${ }^{9}$ For the fathers, we can identify the number of times that he appears in the registrar and his sentences for three time periods: pre-1953 (before the birth of the cohort member), 1953-1959 (until the cohort member is six) and 1959 - 1972 (until the cohort member is 19). Possible sentences are probation (which includes a fine), imprisonment, and exemption from punishment due to psychiatric care or alcohol treatment. Our ability to characterize the extent of the father's criminality is limited by the fact that we do not know the types of crimes committed or the length of time in prison. However, we can still characterize incarcerated fathers as more severe criminals than nonincarcerated fathers or fathers with multiple sentences as more criminal than fathers with just one sentence, etc. We can also identify whether the father was charged with drunk or dangerous driving during each of these time periods.

Lastly, we will use an extensive set of controls in this study to help disentangle the source of the intergenerational criminal relationship. Registry data is available for a wide range of variables characterizing social background, including: residential district, social class, nationality, family composition, marital status, employment, means tested social assistance, income, and education. We will also use a number of variables to control for inherent ability, including: a sixth grade test of intelligence, a second test of intelligence (for males) taken at the start of compulsory military service, and school grades.

\footnotetext{
${ }^{9}$ In the original Stockholm Metropolitan Study, fathers were identified using 3 sources; (1) the 1964 national register of population and income, (2) information from the parish register's office from 1953, and (3) interviews with the cohort members' mothers. The primary goal was to collect information on "rearing" or "social" fathers, hence, fathers may be biological-, adoptive-, or step-fathers. The data on fathers' criminality was extracted from the 1973 official police register. Criminal records can be matched to individuals by using their national registration numbers. All people living in Sweden have such a number. All fathers were re-identified before collecting their crime records. Fathers were identified by comparing the 1967 national register of population and income with the cohort members' address cards for 1967. If these did not match, then the father's identity was double checked against the 1964 national register of population and income. If no father could be identified in this manner, then the delivery records and parish registers from 1953 were searched in an attempt to find the father's national registration number. This process resulted in 1 boy and 3 girls having two fathers with criminal records. In these cases, the criminality records of both fathers were summed together. 122 fathers ( 0.8 percent) could not be identified in this manner. These unidentified fathers are distributed equally between cohort boys and girls.
} 


\section{Descriptive Statistics}

Table 2 presents variable definitions and summary statistics for the cohort member and father crime variables, broken down by sons and daughters. Not surprisingly, females commit much fewer crimes than males. Twenty percent of the male cohort members have a juvenile record while just 6 percent of the girls do. Similarly, 33 percent of males have a record as an adult while just 7 percent of females do. ${ }^{10}$ The higher propensity of males to commit crime is also seen when examining participation in particular crime categories, both as a youth and as an adult. The most common crime for both males and females is theft; 19 percent of males and 4 percent of females have committed a theft. The average number of crimes committed by males in the sample is 3.4 while the female average is less than one half. Again, theft is the dominating crime category when considering this intensive margin. About 12 percent of the fathers have at least one sentence on their record. ${ }^{11}$ Probation is the most common sentence: 8 percent have a

\footnotetext{
10 The Cambridge Study in Delinquent Development follows a sample of London boys also born in 1953. Using this data, Farrington and Wikström (1994) show that the cumulative prevalence of offending between the ages of 10 and 25 are almost identical for the London boys and the Stockholm boys that we study. By age 25, 32.1 percent of the Stockholm boys and 32.6 percent of the London boys had criminal records. Tillman (1987) reports that 33 percent of all men born in 1956 and living in California at the time of his study had been arrested at least once between the ages of 18 and 30. Wolfgang, Figlio and Sellin (1972) report that 35 percent of all Philadelphia men born in 1945 had been arrested by the age of 18. For Denmark, Damm and Dustmann (2007) report that 31 percent of their postreform, male refugees have been convicted of a crime by age 21. Anna Piil Damm was also kind enough to calculate for us that 25 percent of all Danish men have a criminal record by age 30. Although we don't have the exact number in hand, the rate for Copenhagen men is bound to be higher (i.e., closer to the Stockholm rate). We feel that these nearly identical cumulative offending rates across cohorts increases the likely generalizability of our study since it shows that the Stockholm birth cohort offends at similar rates as other cohorts from other metropolitan areas and from other Western countries. Of course, it is important to recognize that there may be other differences that are masked by these similar crime rates, such as the distribution of crimes, reporting rates, and clearance rates.

${ }^{11}$ Williams and Sickles (2002) report that seven percent of the fathers in their sample from the Philadelphia Birth Cohort Study had been arrested at least once during the cohort member's childhood. These data are reported by the son (the cohort member) about his father, which may bias the number downwards since children may not recall or have full information on their fathers' arrest records. Also, the question is formulated so as to exclude any arrests prior to the cohort member's childhood. In Rowe and Farrington's (1997) analysis using a sample of London boys from the Cambridge Study in Delinquent Development, 28 percent of the fathers have a criminal conviction. These data are taken from official police registers, but the fathers are not a representative sample. Nearly all of these fathers (about 94 percent) had a working-class occupation (skilled, semiskilled, or unskilled manual worker). If we look at fathers with a similar socio-economic status in 1963 using the SBC data, we find that 18 percent have been convicted of a crime.
} 
probationary sentence, 3 percent have a prison sentence, 4 percent have a drunken driving sentence, and just one percent receives an exempt sentence.

Table 3 takes a preliminary look at whether children with criminal tendencies are more likely to have criminal fathers. Male cohort members whose fathers have criminal records are 55 percent (17.2 percentage points) more likely to have adult criminal records and commit, on average, 3.77 more crimes than those with fathers without criminal records. Female cohort members whose fathers have criminal records are 142 percent ( 8.4 percentage points) more likely to have an adult criminal record and commit more than three times as many crimes, on average, as those with fathers without a criminal record.

\section{Intergenerational Criminal Correlations}

We begin our empirical analysis by looking at the raw relationship between father and cohort member criminality at the extensive margin in Table 4 and the intensive margin in Table 5. Specifically, Table 4 presents the odds ratios that result from estimating logistic regressions of whether the cohort member has any conviction (overall and in each of the seven crime categories) on whether the father has any sentences (overall and in each of the four sentencing categories). Table 5 presents the incidence rate ratios that result from estimating analogous negative binomial models, where the crime variables are defined as the number of convictions or sentences. At both the extensive and intensive margins, we allow the effects to differ for sons and daughters given the large differences in the number and types of crimes committed by men and women in our sample. ${ }^{12}$ Rather than estimating these regressions separately for sons and daughters, we control for whether the cohort member is female and an interaction between this gender dummy and the father crime variable. Thus, the coefficient on the father crime variable

\footnotetext{
${ }^{12}$ The father-child mechanism may also differ for different types of crimes or by the gender of the child.
} 
tells us the raw father-son relationship while that on the interaction tells us whether the fatherdaughter relationship significantly differs from that with the son and whether it is stronger or weaker. Finally, using specifications that parallel those for the extensive margin, Table 6 considers the relationship between fathers' criminality and their children's delinquent behavior when young in order to see if "criminal" correlations appear early or late in the life of the cohort member.

\section{Extensive Margin Relationships}

An examination of Table 4 indicates that there is clearly a strong relationship between father and son criminality at the extensive margin. Column (1) of Panel A presents the results for the "main" correlation, Father - Crime, i.e. when considering whether the cohort member has any conviction and whether the father has any sentence. Sons whose fathers have at least one sentence have 2.06 times higher odds of having at least one criminal conviction than sons whose fathers do not have any sentence. ${ }^{13}$ The extensive margin relationship between fathers and sons is significant in 35 out of the 40 regressions considered; the five insignificant relationships occur when considering the father's exempt sentences (Panel E). The odds ratios associated with father criminality tend to range between two and three, regardless of the crime and sentencing categories considered. For instance, the odds ratios on the five sentencing categories in column (1) range from 1.99 (the father has a drunk and dangerous driving sentence) to 2.23 (the father has a probation sentence).

\footnotetext{
${ }^{13}$ Earlier versions of the paper estimated correlations rather than odds ratios. The Father-Crime correlation for sons was 0.118 . But, the fact that we are dealing with a dichotomous variable that is not equally distributed between fathers and sons implies that the maximum value that this correlation can take on is less than one. Rather, if each criminal father is assigned to a criminal son, then the maximum possible correlation is 0.52 and the father-son correlation of 0.118 should be judged in reference to this maximum (i.e. $0.118 / 0.52=0.23$ ). Correlations of this sort are useful to put the father-son criminal correlation into perspective and compare it to a more familiar quantity, namely the father - son correlation in earnings. Björklund and Jäntti's (1997) estimate of 0.28 for Swedish fathers and sons is of the same magnitude as our main father - son criminal correlation.
} 
How does the father-daughter relationship compare to that for sons? The odds ratio on the interaction term is significant in just seven out of the 40 regressions, and, in each case, is greater than one; that is, the father-daughter relationship is greater than the father-son relationship. Two of the largest effects are seen in Panel D, which considers paternal drunk and dangerous driving sentences. Over and above the father-son relationship, daughters whose fathers have such a sentence have 2.67 and 2.82 times higher odds of having at least one traffic and narcotic offense, respectively, than daughters whose fathers do not have any drunk and dangerous driving sentences.

\section{Intensive Margin Relationships}

Table 5 indicates that there is also a strong relationship between the number of fathers' sentences and the number of sons' convictions, i.e. at the intensive margin. ${ }^{14}$ As seen in Column (1) of Panel A, one additional sentence of the father increases the expected number of sons' convictions by 32 percent; the incidence rate ratio (IRR) is 1.32 . Significant relationships of a similar magnitude are seen for each of the seven crime categories in Panel A (IRRs range from 1.26 for fraud to 1.40 for violent crimes). These relationships tend to be even stronger when looking at the specific types of fathers' sentences. ${ }^{15}$ For instance, one additional probation sentence obtained by the father increases the expected number of sons' convictions by $68 \%$ (Column (1), Panel B) while an additional drunk and dangerous driving sentence increases the expected number of sons' convictions by more than 100\% (Column (1), Panel D). The weakest

\footnotetext{
${ }^{14}$ The number of sentences served by the father is not an unproblematic measure of the intensity of criminal behavior of that father. One very long sentence may include many (e.g. 10 or more) serious crimes, while two short sentences may only represent two crimes. This measure of intensity is then correlated with the number of crimes committed by the son, which is our preferred measure of intensity. As a robustness check, we have also correlated the number of fathers' sentences with the number of sons' sentences, resulting in qualitatively the same findings.

${ }^{15}$ Since some fathers have more than one type of sentence, a part of these increases is purely mechanical.
} 
relationship, perhaps surprisingly, is for paternal imprisonment (IRR $=1.25)$. We will return to the role played by incarceration in Section 6 .

There are four instances in which the father-daughter relationship significantly differs from the father-son relationship; three of these indicate a stronger relationship while one indicates a weaker one. The father-daughter intensive margin relationship is stronger (though not necessarily significantly so) than that for sons in 28 of the 40 specifications.

\section{Correlations between Fathers' Criminality and Juveniles' Delinquent Behavior}

Lastly, using information from the Child Welfare Committee files, Table 6 investigates whether these relationships appear early or late in life. We see that our main correlations for sons aged 7 to 12 are significant and of a similar magnitude compared to their adult counterparts in Table 4. In addition, the odds ratios are of a similar magnitude when considering delinquency between ages 13 and 19. The father-daughter relationship when considering delinquency from ages 7 to 12 does not significantly differ from that for sons, but there does appear to be some increase in this relationship as daughters age. Sons whose fathers have any sentence have 2.15 times the odds of having a juvenile delinquency record between the ages of 13 and 19. Over and above this, daughters whose fathers have any sentence have 1.54 times the odds of having such a record.

In all cases, the relationships for children aged 13 to 19 are roughly equal to those found for adult cohort members. Thus, the father-child criminal correlations begin to appear between the ages of 7 and 12 and are fully established between the ages of 13 and $19 .{ }^{16}$ This finding

\footnotetext{
${ }^{16}$ There is significant overlap between the CWC data and the PBR data for those aged 13 to 19. Crime in the SBC data peaks at age 17. Stealing is by far the most prevalent crime at this age. Of those who commit crimes, 12 percent make their debut by age 13. By age 19, 58 percent have made their debut. In the United States, arrest rates peak between age 16 and 18 (Blumstein, 1995).
} 
implies that we should not be looking at actual adult outcomes of cohort members in order to explain the father-child correlation. However, expectations (when young) about the future (when adult) can be used as arguments.

Summary of Correlation Results

Our initial investigation of the father - child criminal correlations can be summarized as follows. (1) Fathers' criminality is strongly related to sons' criminality at both the extensive and intensive margins. (2) The main father - son odds ratio is 2.06 (extensive margin) and the main father - son incidence rate ratio is 1.32 (intensive margin). (2) These relationships are seen across all crime categories. (3) These relationships also persist regardless of whether the father has a sentence of probation, prison, or drunk and/or dangerous driving. There is an insignificant relationship between a fathers' exempt sentence and his son's convictions in five (four) crime categories at the extensive (intensive) margin. (4) Most of the father-daughter relationships are not significantly different than those for sons. (5) Father - child correlations in crime appear between the ages of 7 and 12 and are fully established by age 19.

\section{Explaining Father-Child Criminal Correlations: An Initial Regression Analysis}

\section{Regression Methodology}

As is the case when studying income mobility, there are a number of mechanisms through which intergenerational correlations in criminality may arise. Thus, the second aim of our empirical analysis is to begin to understand why the father - child criminal relationship exists. In particular, we will regress a measure of cohort member $i$ 's criminality, $C_{i h n}^{c}$, on a measure of the father's criminality, $C_{i h n}^{f}$, as depicted in equation (1), adding in a number of 
vectors of controls in a stepwise fashion, where $h$ and $n$ denote household and neighborhood, respectively. These controls are meant to proxy for various potential underlying mechanisms, such as whether the intergenerational criminal correlation can simply be attributed to the fact that both the father and child come from similar social backgrounds. The purpose of these specifications is not to make any statements of causality, but, rather, to see how much of the father-child relationship, $\beta$, can be accounted for by each set of controls.

$$
C_{i h n}^{c}=\alpha+\beta C_{i h n}^{f}+S E S_{i h n} \gamma+A_{i h n} \delta+\text { Unstable }_{i h n} \lambda+S S_{i h n} \varpi+A t t_{i h n} \eta+\mu_{n}+\varepsilon_{i h n}
$$

The first vector of controls, $S E S_{i h n}$, captures the father's socioeconomic status and includes such traditional variables as the father's social class in 1953 and 1963, immigration status, the employment status of the household head in 1960 (typically the father), the father's income in 1963, and the educational attainment of both the mother and father. ${ }^{17}$ The second vector of controls, $A_{i h n}$, proxies for ability. IQ test scores on verbal, spatial, and math components from sixth grade as well as school grades from that year are available for all cohort members. For sons, scores on four tests (instructions, verbal, spatial, and technical) taken upon entering the military provide additional measures of cognitive ability. In addition, we proxy for non-cognitive ability using the score from a psychological evaluation of the son's ability to function under stress. ${ }^{18}$ Since traditional measures of ability, such as test scores and especially grades, are

\footnotetext{
${ }^{17}$ Father's income is only available for a single year. By itself, this is a poor proxy for permanent income and would bias downwards the impacts of parental economic resources (Solon, 1992). Therefore, we also include information about social class, employment, and education in the hopes that they jointly provide an adequate proxy for permanent income.

${ }^{18}$ Another measure of non-cognitive ability, leadership skills, is available from the draft data, but is not included in the analysis due to a large number of missing observations. The importance of non-cognitive skills during adolescence has been emphasized in several recent economic studies (see, e.g., Heckman and Rubenstein 2001 and
} 
potentially influenced by social background factors, we first control for socioeconomic status and then ability, thereby presenting fairly conservative estimates of the role played by inherited ability. ${ }^{19}$

The next vector of controls, Unstable $i h n$, proxies for the stability of the household environment. Included in this vector are measures of alcohol abuse, drunkenness, and mental health of the mother and father from 1953 to $1972 .{ }^{20}$ This vector also includes variables indicating whether either the mother or father died during this time period. These variables are included as a first step in controlling for otherwise unobserved heterogeneity across families with the same socioeconomic status. Not all children in low income families become criminals and not all children in well-off families are non-criminals. There must be some child- or familyspecific shock or heterogeneity, such as household instability, that produces criminals.

Household means-tested social support, $S S_{\text {fam }}$, includes two variables: whether the household received any social support from 1953 to 1972 and the number of years in which they received support. ${ }^{21}$ These social support variables are likely to proxy for both the long run

Osborne Groves 2005) and has a long history within the literature on delinquency, crime and antisocial behavior. For a review of this literature see Miller and Lynam (2006).

${ }^{19}$ Of course, it is also possible that the father's socioeconomic status is partly driven by his ability.

${ }^{20}$ Data on parental mental illness and alcoholism are taken from the Child Welfare Committees. The definition used here is that either the mother or the father has shown symptoms of mental illness or psychiatric problems during the period 1953 - 1972. We know if they suffer from depression or other psychiatric problems, if they are receiving treatment, or if they have committed suicide. In total, 6.5 percent of our parents have mental health problems that have been recorded by the Child Welfare Committees. In total, 4.4 percent of our parents have been classified as alcoholics by the Child Welfare Committees. An additional 1.9 percent have records of "incidents of drunkenness".

${ }^{21}$ The Swedish system of means-tested social support is not targeted at specific groups such as single mothers. All residents who are incapable of supporting themselves are potentially eligible for support. The system is regulated by national legislation, but is administered in the municipalities by social workers who are supervised by local politicians and by the courts. In some cases, social support is paid out in kind. Clients may receive, e.g., a telephone, television, refrigerator, furniture, or public transportation card instead of a cash payment. In our data set, these in kind payments are simply recorded as cash payments. In most cases, social support is paid out in cash on a monthly basis. In some cases, it can be paid out weekly or even daily. During the time period that we are interested in, 1953 1972, cash payments were not routinized. Clients had to meet with their social worker to receive each payment. During most of the $20^{\text {th }}$ Century, five to eight percent of the population received means-tested social support for one or more months each year (Stenberg, 2000). Since WW II, old-age pensioners have been replaced by young families with children as the single largest category of welfare recipients (Stenberg, 2000). In 1950, nine percent of all single-mothers received social support. This number rose to 17 percent during the 1980s (Stenberg, 2000). In our 
socioeconomic status of the household and family heterogeneity. But, we believe that it is a better signal of the latter than the former. Our reasoning follows that of Stenberg's (2000) study of the inheritance of welfare recipiency between generations using the SBC data. He argues that, "Because the main part of Swedish social benefits is universal, families who fall through this economic safety net and must rely on means-tested assistance as their last resort are likely to be a more negatively selected group with respect to different types of social problems. Therefore, we could expect to find a greater representation of non-economic problems here than among welfare families in the United States (p. 233)." In our data, we find that the five strongest predictors of receiving social support are (in order of importance): parental psychological problems, parental alcoholism, single household (predominantly single mothers), "incidents" of drunkenness by the mother, and father's criminality. The median number of years during which our single households received support (for one or more months) is one. For parents with psychological or serious alcohol problems, the median is four and five years, respectively. These simple facts reconfirm Stenberg's (2000) conclusion that families who fall through the safety net provided by the Swedish system of universal social benefits and must rely on means-tested assistance are a more negatively selected group with respect to different types of non-economic, social problems.

Our final vector of family heterogeneity variables, att $_{f a m}$, proxies for household attitudes, which are typically reported by the mother. Two variables are included in this category: whether the cohort member was allowed to be absent from school when not sick and whether he was allowed to smoke.

Lastly, we include neighborhood fixed effects, $\mu_{n}$, where the neighborhood is defined as the cohort member's district of residence in 1963. Cohort members lived in more than 600 such

data set, 21 percent of all cohort members lived in families that received social support at least once during the period 1953 to 1972. The average number of years during which they received support (for one or more months) is 4.88 (4.45). The median number of years during which they received support (for one or more months) is three. 
neighborhoods at age 10 . However, they are not evenly distributed across these neighborhoods; 140 neighborhoods include just one cohort member. The mean number of cohort members from the same neighborhood is about 23 . Such fixed effects could potentially capture information about the community's economic status, criminality, schools, peers, etc. Clearly, neighborhood characteristics such as these may help explain an individual's propensity to engage in crime. ${ }^{22}$ But, there are also a number of reasons why such characteristics can potentially explain some of the father - child crime relationship. One simple possibility is that the neighborhood characteristics are common to both the father and the son. However, it is also possible that the neighborhood in which a child lives is chosen by his father and that this choice may not be exogenous to the father's criminality. For instance, the father may choose to live in a neighborhood where his criminal record has less of a stigma. Alternatively, it may be that the father's criminal record limits the set of neighborhoods in which he can choose to live. Therefore, fixed effects may also account for some of the father - child relationship as a result of the father's criminality indirectly affecting the neighborhood in which the child grows up. ${ }^{23}$

\section{Main Extensive and Intensive Margin Results for Sons and Daughters}

Table 7 presents extensive margin results estimated separately for sons and daughters in Panels A and B, respectively, and intensive margin results in Panels C and D. Logistic regressions are estimated at the extensive margin and odds ratios are reported. That is, in Panels A and B, we are considering whether or not the father has any sentence prior to 1972 and

\footnotetext{
${ }^{22}$ Evidence of this is provided by Ludwig, Duncan, and Hirschfield's (2001) and Kling, Ludwig, and Katz's (2005) analyses of the Moving to Opportunity (MTO) experiment. For instance, the latter finds that, relative to control groups, the offer to relocate to lower-poverty areas reduces arrests among female youths for violent and property crimes and arrests among male youths for violent crimes, though an increase in property crime and other problem behaviors was also observed for males.

${ }^{23}$ The vectors of controls were chosen to proxy for the potential mechanisms underlying the father-child crime relationship (beta). As such, known determinants of an individual's criminality, such as education, are not included in these specifications.
} 
whether the cohort member has an adult record through the first half of 1984. In Panels C and D, we estimate negative binomial models using the number of father's sentences and the number of cohort member convictions through 1984. For the sake of brevity, only the odds ratios and IRRs corresponding to father's criminality are reported. Appendix Table 1 presents the full set of extensive margin results for sons, including all of the controls.

Column (1) of Panel A indicates that sons whose fathers have at least one sentence have 2.06 times higher odds of having at least one criminal conviction than sons whose fathers do not have any sentence; this corresponds to the "main" extensive margin relationship for sons presented in Table $4 .{ }^{24}$ Adding in the vector of socioeconomic status controls decreases the father-son odds ratio to 1.68 , or by 36 percent relative to an odds ratio of one. Note that all such calculations will be made relative to an odds ratio of one. Column (3) adds in the ability vector and further decreases the odds ratio associated with father criminality to 1.492 . That is, over and above controls for socioeconomic status, proxies for ability account for approximately 18 percent of the raw father-son criminal correlation. ${ }^{25}$ As stated earlier, this is a conservative estimate of the role of ability; at the other end of the spectrum, ability accounts for 43 percent of the fatherson relationship when it enters the regression prior to socioeconomic status.

Column (4) adds in the unstable household controls, which further drive the father-son odds ratio to 1.308 , and accounts for an additional 17 percent of the relationship. It is important to recognize that this is after controlling for both socioeconomic status and ability, which are both likely to be related to the household instability measures. And, if the household instability measures were to enter the regression first, then they would decrease the father- son odds ratio

\footnotetext{
${ }^{24}$ Marginal effects resulting from estimating equation (1) with a probit indicate that sons with criminal fathers are, on average, 55 percent (17.2 percentage points) more likely to have a criminal record themselves.

${ }^{25}$ Controlling for non-cognitive ability has virtually no effect on the odds ratio associated with father criminality, over and above the cognitive ability controls, though non-cognitive ability is itself a significant predictor of son's criminality. Sons with higher non-cognitive ability are significantly less likely to have a criminal record.
} 
from 2.06 to 1.644 , or by the same amount as the vectors of common background and ability controls. Finally, controlling for social support in Column (5) decreases the father-son odds ratio to 1.211 , or by an additional nine percent. Controls for household attitudes and neighborhood fixed effects have little additional effect on the father-son relationship. Even with the complete set of controls, there is still some portion of the father - son crime relationship that is left unaccounted for: sons with criminal fathers have 1.288 times the odds of having a criminal record than sons with non-criminal fathers (see Column (7) of Panel A in Table 7).

The pattern of extensive margin results for daughters presented in Panel B of Table 7 is very similar. Column (1) indicates that daughters whose fathers have at least one sentence have 2.657 times the odds of having a criminal record themselves. Controlling for socioeconomic status decreases this odds ratio to 2.272 or, relative to one, by 23 percent. Over and above this, controlling for cognitive ability decreases the odds ratio to 1.995 (17 percent). The vector of household instability controls pushes the father-daughter odds ratio to 1.641 (21 percent) and the social support variables push it to 1.530 (7 percent). As is the case for sons, some of the fatherdaughter crime relationship is left unaccounted for when including the full set of controls.

Panel $\mathrm{C}$ of Table 7 presents the intensive margin results for sons. Here we want to assess whether the mechanisms underlying this intergenerational dose response differ from those underlying our extensive margin results. Column (1) of Panel C corresponds to our "main" intensive margin correlation for sons in Table 5 and indicates that one additional sentence of the father increases the expected number of sons' convictions by 32 percent. The socioeconomic status controls included in Column (2) account for 34 percent of this relationship, decreasing the IRR to 1.210 . Over and above this, the vector of cognitive and non-cognitive ability controls 
account for an additional 24 percent. Household instability in Column (4) accounts for a further 20 percent and social support in Column (5) for an additional 11 percent.

Thus, for sons, common background, ability, household instability, and social support each appear to account for approximately the same proportion of the father-son relationship when comparing the extensive and intensive margins. The same cannot be said for daughters, as seen in Panel D of Table 7. While socioeconomic status accounted for more than 20 percent of the father-daughter relationship at the extensive margin, it accounts for less than 3 percent at the intensive margin. Ability and household instability, however, still play important roles and account for an additional 20 and 10 percent respectively of the father-daughter intensive margin relationship. On the other hand, social support has little additional effect. Finally, household attitudes account for an additional 23 percent, whereas this vector of controls played no role in any of the previous specifications. ${ }^{26}$

To summarize, Table 7 indicates that both social background factors and inherited ability play potentially important roles in explaining both the father-son and father-daughter criminal correlations. It is also clear, however, that much heterogeneity exists across households even after controlling for social background. The three vectors of household heterogeneity controls (i.e. instability, support, and attitudes) together account for almost one-third of the intergenerational relationships for both sons and daughters at both the extensive and intensive margins. In addition, though not identical, the pattern of results for sons and daughters tell the same general story. ${ }^{27}$ Finally, because neighborhood effects do not seem to play a significant

\footnotetext{
${ }^{26} \mathrm{Keep}$ in mind that it is almost exclusively mothers who are being asked about their attitudes. So the fact that mothers' attitudes matters for daughters, but not sons, could be an indication of a gender-specific transference of behavior and attitudes from mothers to their daughters.

${ }^{27}$ This is consistent with Moffitt et al. (2001) who found that the same set of risk factors predicted antisocial behavior in both males and females. They argue that the large difference in the level of antisocial behavior between males and females is largely due to the fact that males have a higher exposure to these risk factors.
} 
role at either the extensive or intensive margins, and because they are asking a lot of the data, we exclude them from the remainder of the analysis.

Explaining the Relationship between Father and Child Criminality by Type of Crime

Table 8 explores whether the intergenerational father-son correlations, at both the extensive and intensive margins, differ when looking across crime categories. At the extensive margin, odds ratios range from 2.481 and 2.267 for violent and theft offenses, respectively, to 1.861 for traffic offenses when excluding all controls. Controlling for both socioeconomic status and ability account for between 54 and 69 percent of the raw father - son relationships, depending on the crime category; the largest impact is for narcotics and the smallest for thefts. Once the full set of controls is included, the father - son extensive margin relationships can be fully accounted for, i.e. becomes insignificant, in all cases except thefts (which is the most prevalent crime in our data set). At the intensive margin, the strongest raw intergenerational relationship is for violent offenses (IRR $=1.401)$ and the weakest is for fraud $(\mathrm{IRR}=1.253)$. Social background and ability account for between 53 (narcotics) and 76 (violent) percent of this relationship. All of the IRRs are insignificant when including the full set of controls.

\section{Explaining Father-Son Criminal Correlations: Can We Identify a Direct Effect?}

\section{Sibling Correlations}

The Stockholm birth cohort includes 144 identifiable pairs of twins. This enables us to study the importance of fathers' criminality and other family background effects by calculating sibling correlations in criminal behavior. ${ }^{28}$ Sibling correlations can be viewed as omnibus

\footnotetext{
${ }^{28}$ Rowe and Farrington (1997) is one of several previous studies that have examined the importance of family background for criminal behavior by examining sibling correlations. Other examples include Snell (1993), Johnson
} 
measures of the importance of family and community effects. They include anything shared by siblings (e.g., parental characteristics, such as fathers' criminality), as well as things not directly experienced in the home (e.g., school, church and neighborhood effects). Genetic traits not shared by siblings, differential treatment of siblings, time-dependent changes in neighborhoods, schools, etc. are all excluded from this correlation.

The data also allows us to distinguish between monozygotic and dizygotic twins. ${ }^{29}$ Comparing sibling correlations in criminal behavior of the two types of twins gives us a direct measure of the potential importance of inherited traits for criminal behavior and, hence, a direct (genetic) link between fathers' criminality and that of their children. If genetics matter, then the correlation between monozygotic twins criminal behavior should be larger than that found for dizygotic twins. $^{30}$

We first examine whether or not these 288 individuals differ in any significant way from the rest of our sample in terms of their criminal behavior and their fathers' criminality. We find that 31 percent of the male twins are in the official police registrar (PBR) as compared with 33 percent in the full sample. The mean number of crimes committed is also roughly equal between these two groups. Female twins appear somewhat less frequently in the PBR than females in the full sample, 5 percent versus 7 percent, respectively. The mean number of crimes committed is

(2007) and Mazumder (2008). There is also a large literature concerned more specifically with twins' correlations in criminal and other antisocial behaviors (see, e.g., Rowe 1986 and Ishikawa and Raine 2002).

${ }^{29}$ The zygosity of these twins has been determined by matching cohort members to the Swedish twins register maintained by Karolinska Institutet. They deem that monozygotic twins can be classified with up to 99 percent certainty, while dizygotic twins can be classified up to 95 percent certainty.

${ }^{30}$ For a review of the existing twins studies that use monozygotic (MZ) and dizygotic (DZ) twins differences to study the effect of genetics on the predisposition to commit crime see Ishikawa and Raine (2002). They also discuss the potential limitations of this identification strategy. Parents of MZ twins may treat them more similarly than the parents of DZ twins treat their children. In this case, parental treatment could bias the MZ sibling correlation upwards. On the other hand, if MZ twins strive to differentiate themselves from each other, then this would bias MZ sibling correlations downwards. There can also be greater differences in the birth weights of MZ twins than DZ twins due to the foeto-foetal transfusion syndrome. MZ twins also run a higher risk of certain perinatal complications. Such non-genetic, biological factors may bias MZ correlations downwards. There is evidence that all of these biases do, in fact, exist to some degree. However, Rutter et al. (1990) suggest that they cancel each other out. 
also lower for our sample of female twins. There are, however, only 6 female twins in the PBR and we never find both female twins from the same family in the PBR. This means that we cannot identify a separate family effect using a sample of female twins only. We can, however, use these observations when estimating sibling correlations for the whole sample of twins and for mixed gender twins. ${ }^{31}$

Table 9 presents a set of sibling correlations in criminal behavior at the extensive and intensive margins. If inherited traits account for a large part of the sibling correlation, then we should be able to order them from highest to lowest as follows: monozygotic (MZ), unknown zygosity (MZDZ), all twins (All), dizygotic twins (DZ). This is exactly what we find for the extensive margin sibling correlations calculated using the entire sample of twins (see Table 9). However, the correlation for monozygotic twins is not statistically significantly larger than the correlation among dizygotic twins. Furthermore, the sibling correlations calculated using male twins only actually produce a higher correlation for dizygotic twins than for monozygotic twins, albeit not significantly higher.

In Table 9, we see that the sibling correlations in Crime at the extensive margin are always significantly larger than zero for all categories except male MZ twins. A sibling correlation of 0.48 (for the category all male twins) implies that almost half of the variation in male criminality at the extensive margin can be attributed to family background and community effects. ${ }^{32}$ But, we do not find evidence in favor of a direct (genetic) link between the criminality of fathers and their children at the extensive margin, at least not in our aggregated crime variable.

\footnotetext{
${ }^{31}$ We have a seventh female twin that we cannot match to a twin brother or sister (and is, therefore, excluded from the twins sample) that is highly criminal with a total of 29 crimes recorded in the PBR. Including this female in the twins sample raises the mean number of crimes committed by female twins to roughly the same level as the full sample.

${ }^{32}$ Estimates of brother correlations in income and in years of schooling for comparable Swedish birth cohorts are approximately 0.25 and 0.45 , respectively (Björklund et al. 2009). Using data from the Cambridge Study in Delinquent Development, Rowe and Farrington (1997) report sibling correlations in criminal convictions of 0.45 -
} 
Similar results hold for the sibling correlations at the intensive margin shown in Table 9. Once again, our small samples hinder us from investigating the differences between monozygotic and dizygotic twins. We do see, however, that the overall importance of family background and community effects is even larger for criminal intensity. A sibling correlation of 0.63 (for the category all male twins) implies that nearly two-thirds of the variation in the criminality of men at the intensive margin can be attributed to family background and community effects.

We have also calculated sibling correlations at the extensive and intensive margins for our seven crime categories. ${ }^{33}$ The only two categories that appear to support the idea that MZ correlations may be higher than DZ correlations are also the two most frequently committed crimes, stealing and serious traffic offences. We take a closer look at these correlations in Table 9. For stealing, we find no significant difference between the correlations for MZ and DZ twins. The average sibling correlation in stealing for men at both margins is statistically significant and equal to 0.43 . Thus, family background (including fathers' criminality) and community effects account for 43 percent of the variation in stealing found in the twins data.

The case of serious traffic offences results in a different picture. Family background matters, but we also find that the MZ correlation is always significantly larger than the DZ correlations. We interpret this result, together with our earlier results concerning the unusually strong father - daughter correlations between fathers' drunk and dangerous driving and

0.50 for same-sex siblings and of 0.27 for opposite-sex siblings. Using NLSY79 data, Mazumder (2008) estimates sibling correlations in illegal drug use for brothers, sisters and all siblings of $0.300,0.371$ and 0.268 , respectively. He also reports extensive margin correlations for spending time in jail of $0.263,0.000$ and 0.152 , respectively. Using data from the PSID, Johnson (2007) reports brother and childhood neighborhood correlations for adult incarceration of 0.69 and 0.54, respectively. Snell (1993) finds that nearly one-third of all inmates in U.S. states prisons in 1991 report having a brother who has also been incarcerated.

${ }_{33}$ Our sample of twins is too small for us to say anything about violent crimes and narcotic crimes. The sibling correlation for fraud is zero and for "other" we find a zero correlation for both MZ and DZ twins. DZ twins have a stronger sibling correlation in vandalism than MZ twins. But this is due to having too few MZ twins in this category. 
daughters' traffic and narcotics offences (Panel D in Table 4), as indicators that inherited traits may be of particular importance for explaining serious traffic offences. We believe that this is mainly due to the prevalence of drunk driving in this category. In future research, we intend to investigate the importance of family background (both social and inherited) more carefully for drunk driving. ${ }^{34}$

\section{Adoptee Analysis}

The Stockholm birth cohort also includes 258 individuals who were adopted by either two parents or by the spouse of the birth mother or father. Of these, 252 individuals have adoptive fathers (141 females and 111 males). In these cases, our crime data refers to the adopting father and not to the individual's biological father. If the intergenerational relationship is the same, or stronger, for adopted individuals, then this points towards the importance of environmental rather than genetic factors. A weaker relationship indicates that genetics also matter. Specifically, we estimate regression (1), expanding it to include controls for whether the cohort member was adopted and an interaction between whether the cohort member was adopted and his or her father's criminal record.

The results of this specification for males and females at both the extensive and intensive margins are presented in Table 10. Examining the extensive margin results first, we see that adopted cohort members are more likely to have a criminal record themselves, though this result is only significant for females. The odds ratio associated with the interaction term is always less

\footnotetext{
${ }^{34}$ Carey (1992) suggests that MZ twins may influence each other more than DZ twins do. This type of "peer" effect would bias MZ correlations upwards relative to DZ correlations. We have examined co-offending among our twins in order to see if this may be what is driving our result concerning serious traffic offences. 39 of our 144 twin pairs include at least one twin with a conviction. In 11 of these pairs, both twins have been convicted at least once. Of these 11 pairs, 2 pairs have conviction dates on the exact same day for the same type(s) of crime(s). One of these 2 pairs actually has two sets of shared conviction dates. Neither of these 2 pairs is classified as MZ twins. They both have unknown zygosity and are, therefore, placed in the MZDZ category. 3 pairs of MZ and 4 pairs of DZ twins have convictions less than 12 months apart. $1 \mathrm{MZ}$ pair and 1 mixed-gender DZ pair have only distant convictions.
} 
than one and large enough to cancel out the father-child association, but it is insignificant for both males and females. At the intensive margin, we find that the IRRs associated with Adopted are significant and large for both sons and daughters. The interaction term, however, is only significantly less than one when considering adopted daughters. It is large enough to offset the effect of having a criminal father. We feel that these results provide weak evidence in favor of the importance of inherited traits. ${ }^{35,36}$

\section{Timing of Fathers' Crimes}

Another way to get at the mechanisms underlying the intergenerational criminal correlations is to consider the timing of the fathers' crimes. If these intergenerational relationships are completely driven by genetics, then the timing of the fathers' crime, i.e. before or after the cohort member's birth, should not matter. Similarly, the timing of the crime should not matter if common background effects are the driving factor. ${ }^{37}$ In contrast, if a father's criminality causes his child to engage in criminal activities by setting a bad example (a role model hypothesis), then the timing of the father's crimes should matter. Crimes committed

\footnotetext{
${ }^{35}$ Ideally, one would like to look at individuals adopted by both parents at a young age separately from those adopted by only a father, perhaps as a mother remarried later in life. Our ability to do this is even more limited by sample size than our main adoption analysis. We can identify only 61 cohort members ( 39 sons and 22 daughters) who were adopted by both parents before age 6 . Replicating the above specifications, we find very similar results for daughters. The odds ratios and IRRs associated with the interaction term are less than one, but only strongly significant at the intensive margin, pointing towards the importance of inherited traits. But, for the sample of sons, the interaction terms are much greater than one, though very imprecisely measured.

${ }^{36}$ Studies with access to larger samples of adoptees find much stronger evidence of the heritability of criminal behavior. For example, Mednick, Gabrielli, and Hutchings (1984) find a significant relationship between the criminal records of more than 14,000 Danish adoptees and their biological parents but not between adoptees and their adoptive parents. Bohman et al. (1982) studied 862 Swedish men who were adopted by non-relatives at an early age. They found that non-alcoholic, petty criminals had an excess of biologic parents with histories of petty crime and no alcohol abuse.

${ }^{37}$ Crimes due to schizophrenia or any other potentially inherited illness that manifests itself at specific ages would nullify this identification strategy. Alternatively, if the father's behavior acts as a catalyst for his son's genetic predisposition to commit crime, then the interpretation of our timing experiment is less of a role model effect and more of an interaction effect between the father's behavior and the son's genetic predisposition.
} 
before the child is born or when he is just an infant should matter less than crimes committed when the child is aware of the importance and/or meaning of such an event.

We test this role model hypothesis by placing our criminal fathers into three categories: (i) those who only have sentences before 1953, (ii) those who only have sentences after 1953, and (iii) those who have sentences in both periods. Then we test whether the father - child criminal association is larger for the post-1953 criminal fathers and their children than for the pre-1953 criminal fathers and their children. A larger post-1953 coefficient means that the timing of fathers' crimes matters and is evidence in favor of the role model hypothesis.

Table 11 presents these results for both males and females. Juvenile delinquency at the extensive margin is the dependent variable in columns (1) and (2) while adult criminality at the extensive and intensive margins is considered in columns (3) through (6). In all cases, the post1953 estimates are larger than the pre-1953 estimates. In addition, these differences are statistically significant in three specifications: male juvenile delinquency $(\mathrm{p}=0.0133)$, adult male crime at the intensive margin $(\mathrm{p}=0.0684)$, and adult female crime at the intensive margin $(\mathrm{p}=0.0254)$. Thus, we conclude that the timing of fathers' criminality matters, especially for those children (in particular sons) who will later become repeat offenders. This finding is evidence in favor of the father as a role model hypothesis.

A potential concern with this analysis is that fathers who commit crimes prior to 1953 systematically differ from those who commit crimes after 1953. In particular, are those who commit post-1953 crimes more serious criminals, since one may expect that only these individuals will still be committing crime when their children are older? Our first response to such a critique is that we focus on fathers who only commit crimes before or after 1953. Thus, 
those committing crimes after 1953 are not necessarily worse criminals; they have not built up a criminal history prior to $1953 .^{38}$

We then look at a number of observables to assess whether these two groups still systematically differ. While they do not differ in terms of background (e.g. education and income), they do statistically differ in terms of type of sentence and birth year. Fathers with pre1953 sentences only are significantly more likely to have a prison sentence (though this difference is insignificant at the intensive margin) and a probation sentence while those with post-1953 sentences only are significantly more likely to have a drunk and dangerous driving sentence. Because of these observable differences, we conduct additional robustness tests. First we find that our results are not sensitive to controlling for father's year of birth. We also redo the timing experiment using incarceration rather than any sentence; that is, we compare fathers who have a prison sentence prior to 1953 only to those with such a sentence after 1953 only. Once again, the post-1953 estimates are always greater than the pre-1953 estimates. Despite the loss of precision due to the fact that less than four percent of fathers have any prison sentence, four of the six p-values resulting from tests that compare the pre and post estimates are less than 0.23.

\section{Quality of the Father - Child Relationship}

Mothers in a sub-sample of the Stockholm Birth Cohort were interviewed in 1968, when the cohort members were 13 years old. ${ }^{39}$ One of the questions that they were asked was; "How would you characterize the relationship between your husband and your son/daughter?" Mothers were asked to answer on a scale from 1 to 5, ranging from "unusually good" to "unusually poor".

\footnotetext{
${ }^{38}$ Of course, this does not rule out the possibility that individuals with only post-1953 sentences committed crimes prior to 1953 , but were not caught.

39 For a complete description of the Family Survey and the Family Survey Sample see Codebook I at http://stockholmbirthcohort.su.se/. For evidence concerning the overall representativeness of the Family Survey Sample see Björklund et al. (2008).
} 
We use this question in a second test of the father as a role model hypothesis. One may expect that children with "unusually good" relationships with their fathers may be more likely to behave as their fathers do than those with neutral or "unusually poor" relationships with their fathers.

We have 1,636 males and 1,563 females in this sub-sample. Approximately 18 and 5 percent, respectively, of these sons and daughters have juvenile records and 12 and 10 percent of their fathers have criminal convictions; this compares to the full sample where 19 and 6 percent of sons and daughters have such records while 12 and 13 percent of their fathers do. ${ }^{40}$ Since the median answer to the above question was "unusually good", we have had created a dichotomous variable which we call "closeness". It is equal to 1 if the mother answered "unusually good" and zero otherwise.

Table 12 presents the results of adding our measure of closeness to the baseline logistic regression together with an interaction term of this variable and fathers' crime. It is this interaction term that we are most interested in. An odds ratio that is significantly greater than one implies that children with a close relationship with their father also have a relatively stronger father - child criminal association.

We find that our measure of "closeness" is a strong predicator of juvenile delinquency for both sons and daughters. Those with low quality relationships with their fathers are much more likely to have a record of juvenile delinquency. More importantly, the odds ratio for the interaction term is much larger than one (1.966 for sons and 1.910 for daughters) and is statistically significant for sons. This means that sons who have an "unusually good" relationship with their fathers (as characterized by their mothers) behave more like their fathers - for better or

\footnotetext{
${ }^{40}$ In this experiment, we focus only on juvenile delinquency, since the question was posed to these mothers in 1968 when their children were 13 years old.
} 
for worse - than those with lower quality relations. We interpret this as evidence in favor of the father as a role model hypothesis.

\section{Paternal Incarceration as an Intervention?}

This final sub-section considers how the intervention of incarceration impacts the intergenerational transmission of criminality. Is there an effect over and above the effect of having a criminal parent? One possibility is that the child is less likely to engage in crime as a result of removing a bad influence from the household. Similarly, the child may update his beliefs about the chance of punishment, and commit fewer crimes as a result. Alternatively, having an incarcerated father could potentially increase a child's criminal behavior as a result of the affiliated stigma, having less supervision in the household, or the general instability such an event could cause in the household. The existence of such an incarceration effect, regardless of whether it is positive or negative, points towards the importance of a behavioral transference mechanism. If incarcerating fathers pushes children into poverty, then this social mechanism could also lead to an increase in criminal behavior. ${ }^{41}$

We begin to explore this question in Table 13 by running extensive margin regressions similar to those reported in Murray et al. (2007). In fact, these authors have already used the SBC data to study whether paternal incarceration predicts child criminality, over and above paternal conviction. Specifically, they estimate logistic regressions where they control for the number of post-1953 fathers' convictions and whether the father was incarcerated after 1953; they find that paternal incarceration does not significantly improve the prediction of cohort member offending

\footnotetext{
${ }^{41}$ See Murray (2005) and Johnson (2009) for reviews of the literature concerning the impact of incarceration on families and children.
} 
over and above paternal conviction. ${ }^{42}$ Columns (1) and (6) in Table 13 confirm this result with regards to juvenile delinquency for our sons and daughters while columns (2) and (7) confirm this result for their criminal behavior as adults.

We then go on to investigate the effect of paternal incarceration at the intensive margin, which is not studied in Murray et al. (2007). We first estimate logit regressions of whether the cohort member has any adult convictions on both the number of post-1953 fathers' sentences and prison sentences in columns (3) and (8). One additional sentence of any sort of the father is associated with significantly greater odds of having an adult record (odds ratios of 1.421 and 1.461 for sons and daughters, respectively). But, over and above this, one additional prison sentence of the father significantly decreases the odds of having an adult record (odds ratios of 0.719 and 0.711 , respectively). This offsetting effect of paternal incarceration is also seen when estimating negative binomial regressions of the number of adult cohort member convictions on both the total number of paternal sentences and the number of paternal prison sentences in columns (4) and (9). Specifically, one additional sentence of the father increases the expected number of son's (daughter's) convictions by 68 (125) percent, but one additional prison sentence significantly decreases the expected number of son's (daughter's) convictions by 37 (54) percent.

What does this relationship mean and why is it only observed at the intensive margin? One possibility is that removing the father from the household only has an effect if prison sentences are sufficiently long or numerous. Another possibility is that the intensive margin allows us to identify the 'worst' fathers, and removing these individuals from the home has the most beneficial effect. In fact, we can make this significant intensive margin result insignificant

\footnotetext{
${ }^{42}$ In contrast to this, Murray et al.'s (2007) results using U.K. data show that there is an added effect of incarceration on children's criminality even after controlling for parents' criminal convictions.
} 
by simply removing fathers with the greatest number of prison sentences. We only need to remove 34 fathers with a son (each having four or more post-1953 prison sentences) and 10 fathers with a daughter (each having six or more post-1953 prison sentences) in order to make these intensive margin relationships insignificant (see columns (5) and (10) in Table 13.

It may, however, be the case that these fathers were not present in the household even before they were incarcerated and have, therefore, not been around to influence their offspring. This would imply that it is not incarceration, but rather the behavior of the child's mother and/or the structure of the child's family that produces these intensive margin results. Mumola (2000) examines this question for the U.S. and reports that 56 percent of state-inmate fathers and 45 percent of federal-inmate fathers were not living with their children at the time of admission.

To get a first indication of the relative importance of family structure versus incarceration, we break our sample into three groups of children by the number of post-1953 prison sentences of their fathers: (i) the $34+10$ fathers with the highest number of post-1953 prison sentences, (ii) those with fewer prison sentences, and (iii) those with no prison sentence. 35, 23 and 8 percent of sons in each of these groups, respectively, were living in female-headed households in 1960. Similar numbers hold for daughters. These figures speak more in favor of family structure as the mediating factor driving this intensive margin result as opposed to incarceration. At the very least, they suggest the need for further work on the importance of family structure when trying to understand father - child criminal associations.

\section{Summary of Results and Policy Implications}

We conclude with a summary of our main findings and a discussion of the generalizability of these results as well as their implications for policy makers. Our analysis of 
the raw data finds strong evidence of an intergenerational criminal correlation. This relationship is seen for both sons and daughters, at both the extensive and intensive margins, and across cohort member crime and father sentencing categories.

Taken together, our regression analyses indicate that both social background factors and inherited ability play potentially important roles in explaining both the father-son and fatherdaughter criminal correlations. Specifically, socioeconomic status accounts for roughly one-third of the father-son intergenerational criminal relationship and somewhat less, particularly at the intensive margin, for daughters. Over and above this, for both sons and daughters, our ability proxies account for an additional 20 percent. It is also clear, however, that much heterogeneity exists across households even after controlling for social background. The three vectors of household heterogeneity controls, and household instability in particular, together account for almost one-third of the intergenerational relationships. We conclude, therefore, that being poor is not always enough to make young adults commit crimes. Rather, it appears that it is the unfortunate combination of fathers' criminality and parental instability that are most important, which, in turn, implies a behavioral model of intergenerational criminal correlations.

We also conducted four alternative experiments that provide more direct evidence concerning the father's role in producing criminal outcomes in his children and that provide support of two, particular direct channels: (1) inherited traits, and (2) the father as a role model. First, our analysis of sibling crime correlations for the sample of twins reaffirms the importance of family background for explaining crime. In addition, the sibling correlations for drunk and dangerous driving were significantly greater for monozygotic twins than dizygotic twins, providing direct evidence that genetics matter for this crime category. The analysis of adopted children provided weak evidence of the importance of genetic factors, especially for repeat 
offenders. Both of these analyses suffer, however, from sample size issues and point towards the importance of future research.

Our last two 'experiments' were meant to test the father as a role model hypothesis. We found that the timing of the fathers' crime mattered for the criminality of the children. We also found that sons who have an "unusually good" relationship with their fathers (as characterized by their mothers) behave more like their fathers - for better or for worse - than those with lower quality relations. We interpret the results of these two experiments as evidence in favor of a role model hypothesis, especially for juvenile sons.

Finally, we study the effect of parental incarceration on the children. This is an important question given the increasing numbers of children with incarcerated parents. A 2000 U.S. Bureau of Justice Statistics report estimates that 721,500 State and Federal prisoners were parents to $1,498,800$ children under age 18 in 1999 . We find evidence that such an intervention may actually be beneficial to the children. But we can not distinguish this mechanism from other possible mechanisms, such as family structure and the behavior of the mother. Regardless of the precise mechanism, this tentative finding still speaks in favor of a behavioral transference mechanism.

Given that we study a specific cohort of individuals born in 1953 and living in Stockholm in 1963, it is certainly important to discuss how our findings may extend beyond Sweden. On the one hand, there are a number of arguments to make in support of the generalizability of our results. First, as demonstrated previously, Sweden is not a country free from crime and our cohort of Swedish men has similar cumulative offending rates as comparable samples of men in London, California, Philadelphia, and Denmark (see Section 2). In addition, if one believes that genetics matters for criminal behavior, then these types of arguments should not be Sweden 
specific. Finally, the criminology literature has documented similar trends and patterns in the development and structure of crime in Sweden, Western Europe and North America (Westfelt 2001, Sarnecki 2003); that is, there is no Sweden-specific theory of crime (Sarnecki 2003).

On the other hand, one has to recognize the unique nature of Sweden's social welfare policies, which provide an economic safety net to all Swedish citizens. Policies such as these could feasibly mitigate the effect of having a criminal parent. This may be particularly relevant in the context of our incarceration analysis. Would we have found the same beneficial effect on the children if their economic well-being were not protected during the time that their father was incarcerated? It is also important to consider how Swedish incarceration may differ from that in other countries. Prison sentences in Sweden (historically and today) tend to be shorter than in other western countries, such as the U.S. and Great Britain (see e.g. Marnell 1972 and Pratt 2008). In addition, as described in Murray, Janson, and Farrington (2007), Swedish prison policies tend to be more family friendly; for instance, many prisoners had the right to home leave every few months and could communicate with their families via telephone and uncensored mail. These policies could certainly play a role in explaining the findings of our incarceration analysis.

Finally, an understanding of the mechanisms underlying intergenerational criminal correlations can help create policies. Our research points to three such mechanisms: (i) common socio-economic background, (ii) inherited traits, and (iii) behavioral mechanisms, such as parental instability and the father's importance as a role model for his children. The first implies that policies aimed at reducing poverty also reduce crime. The second factor leads us into a fairly new literature in psychology and behavioral genetics that tries to identify inherited traits and/or conditions that can be used as indicators of which children are more "at risk" and may have a greater need for treatment (see e.g. Moffitt 2005). Lastly, if the observed intergenerational 
criminal correlations are produced by a behavioral model, such as our role model hypothesis, then a new avenue for fighting crime appears feasible. A policy that successfully treats or deters criminal behavior today has a larger impact on total crime than previously recognized, since it also produces a "second generation effect." Our research also shows that children growing up in families that have problems with mental illness and/or substance abuse are particularly susceptible to this behavioral mechanism and to the criminal status of their parents. Future research on the potential interaction effects between nature and nurture will be important to the development of this line of reasoning. ${ }^{43}$ If strong interaction effects exist, then our "second generation effect" will be even larger.

\section{References}

Becker, Gary (1968), "Crime and Punishment: An Economic Approach," The Journal of Political Economy 76, 169-217.

Björklund, Anders and Markus Jäntti (1997), "Intergenerational Income Mobility in Sweden Compared to the United States," American Economic Review 87(5), 1009-18.

Björklund, Anders, Lena Lindahl and Matthew J. Lindquist (2008) "What More Than Parental Income? An Exploration of What Swedish Siblings Get from Their Parents," IZA Discussion Paper No. 3735.

Björklund, Anders, Markus Jäntti and Matthew J. Lindquist (2009), "Family Background and Income during the Rise of the Welfare State: Brother Correlations in Income for Swedish Men Born 1932-1968," Journal of Public Economics 93, 671-680.

Blumstein, Alfred (1995), "Prisons," in James Q. Wilson and Joan Petersilia (eds.), Crime, Institute for Contemporary Studies, California.

Bohman, Micahel, C. Robert Cloninger, Sören Sigvardsson and Anne-Liis von Knorring (1982), "Predisposition to Petty Criminality in Swedish Adoptees," Archives of General Psychiatry 39(11), 1233-1241.

\footnotetext{
${ }^{43}$ Terrie Moffitt (2005) provides an excellent summary of the current state of the science concerning geneenvironment interplay in producing antisocial behavior (such as crime).
} 
Butterfield, Fox (2002), "Father Steals Best: Crime in an American Family," The New York Times, August 21, 2002.

Carey, Gregory (1992), “Twin Imitation for Antisocial Behavior: Implications for Genetic and Family Environment research,” Journal of Abnormal Psychology 101(1), 18-25.

Case, Anne and Katz, Lawrence F. (1991), “The Company You Keep: The Effects of Family and Neighborhood on Disadvantaged Youths,” NBER Working Paper No. 3705.

Corman, Hope and H. Naci Mocan (2000), "A Time-Series Analysis of Crime, Deterrence, and Drug Abuse in New York City,” American Economic Review 90(3), 584-605.

Damm, Anna Piil and Christian Dustmann (2007), "Do Young People Learn Criminal Behaviour? Quasi-Experimental Evidence," Department of Economics, University College London.

Duncan, Greg, Ariel Kalil, Susan Mayer, Robin Tepper, and Monique Payne (2005), “The Apple Does Not Fall Far From the Tree," in Samuel Bowles, Herbert Gintis and Melissa Osborne Groves (eds.), Unequal Chances: Family Background and Economic Success, Princeton University Press.

EU ICS (2005), "The Burden of Crime in the EU, A Comparative Analysis of the European Survey of Crime and Safety," EU ICS report.

Farrington, David and Donald West (1990), "The Cambridge Study in Delinquent Development: a long-term follow up of 411 London males," in H. J. Kerner and G. Kaiser (Eds.), Criminality, Personality, Behavior, and Life History, Berlin: Springer-Verlag.

Farrington, David P. and Per-Olof H. Wiström (1994), "Criminal Careers in London and Stockholm - A Cross-National Comparative Study, in Carl-Gunnar Janson (ed.), "Studies of a Stockholm Cohort," Project Metropolitan Research Report No. 39, Department of Sociology, Stockholm University.

Farrington, David P., Jeremy W. Coid and Joseph Murray (2009), "Family Factors in the Intergenerational Transmission of Offending," Criminal Behaviour and Mental Health 19(2), 109-124

Ferguson, Thomas (1952), The Young Delinquent in His Social Setting, London: Oxford University Press.

Glueck, Eleanor and Sheldon Glueck (1950), Unravelling Juvenile Delinquency, Cambridge, MA: Harvard University Press.

Gregory, Nathan (2004), "Crime and the Family: Like Grandfather, Like Father, Like Son?" The British Journal of Forensic Practice 6(4), 32-36. 
Heckman, James and Yona Rubenstein (2001), “The Importance of Noncognitive Skills: Lessons from the GED Testing Program," American Economic Review 91(2), 145-149.

Ishikawa, Sharon S. and Adrian Raine (2002), "Behavioral genetics and Crime," in J. Glickson (ed.), The Neurobiology of Criminal Behavior, Norwell: Kluwer Academic Publishers, 81-110.

Janson, Carl-Gunnar (1982), "Delinquency among Metropolitan Boys," Project Metropolitan Research Report No 17, Department of Sociology, Stockholm University.

Johnson, Rucker C. (2007), "Intergenerational Risks of Criminal Involvement and Incarceration," Goldman School of Public Policy, University of California, Berkley.

Johnson, Rucker C. (2009), "Ever-Increasing Levels of Incarceration and the Consequences for Children" in Steven Raphael and Michael A. Stoll (eds.), Do Prisons Make Us Safer? The Benefits and Costs of the Prison Boom, New York: Russell Sage Foundation, 177-206.

Kling, Jeffrey, Jens Ludwig, and Lawrence Katz (2005), "Neighborhood Effects on Crime for Male and Female Youth: Evidence from a Randomized Housing Voucher Experiment" The Quarterly Journal of Economics 120(1), 87-130.

Levitt, Steven D. (2002) "Using Electoral Cycles in Police Hiring to Estimate the Effect of Police on Crime: Reply," American Economic Review 92(4), 1244-1250.

Ludwig, Jens, Greg Duncan, and Paul Hirschfield (2001). "Urban Poverty and Juvenile Crime: Evidence From a Randomized Housing-Mobility Experiment" The Quarterly Journal of Economcis, 116(2), 655-679.

Marnell, Gunnar (1972) “"Comparative Correctional Systems - United States and Sweden," Criminal Law Bulletin 8(9), 748-760.

Marvell, Thomas B. and Carlisle E. Moody (1996) "Determinate Sentencing and Abolishing Parole: The Long-Term Impact on Prisons and Crime," Criminology 34(1), 107-128.

Mazumder, Bhashkar (2008), "Sibling Similarities and Economic Inequality in the US," Journal of Population Economics 21(3), 685-701.

Mednick, Sarnoff, William Gabrielli and Barry Hutchings (1984), "Genetic Influences in Criminal Convictions: Evidence from an Adoption Cohort," Science 224(4651), 891-94.

Miller, Joshua D. and Donald Lynam (2006), "Structural Models of Personality and Their Relation to Antisocial Behavior: A Meta-Analytic Review," Criminology 39(4), 765-798.

Moffitt, Terrie E., Avshalom Caspi, Michael Rutter, Phil A. Silva (2001), Sex Differences in Antisocial Behaviour: Conduct, Disorder, Delinquency, and Violence in the Dunedin Longitudinal Study, Cambridge: Cambridge University Press. 
Moffitt, Terrie E. (2005), "The New Look of Behavioral Genetics in Developmental Psychopathology: Gene-Environment Interplay in Antisocial Behaviors," Psychological Bulletin 131(4), 533-54.

Mumola, Christopher J. (2000), "Incarcerated Parents and Their Children," Washington, D.C.: Bureau of Justice Statistics, Special Report, August 2000, NCJ 182335.

Murray, Joseph (2005), "The Effects of Imprisonment on Families and Children of Prisoners," in Alison Liebling and Shadd Maruna (eds.), The Effects of Imprisonment, Cullompton, Devon, England: Willan Publishing, 442-462.

Murray, Joseph, Carl-Gunnar Janson and David P. Farrington (2007), "Crime in Adult Offspring of Prisoners: A Cross-National Comparison of Two Longitudinal Samples," Criminal Justice and Behavior 34(1): 133-49.

Osborne Groves, Melissa (2005), "Personality and the Intergenerational Transmission of Economic Status," in Samuel Bowles, Herbert Gintis and Melissa Osborne Groves (eds.), Unequal Chances: Family Background and Economic Success, Princeton University Press.

Pratt, John (2008) "Scandinavian Exceptionalism in an Era of Penal Excess," British Journal of Criminology 48, 119-137.

Rowe, David C. (1986), "Genetic and Environmental Components of Antisocial Behavior: A Study of 265 Twin Pairs," Criminology 24(3), 513-532.

Rowe, David C. and David P. Farrington (1997), "The Familial Transmission of Criminal Convictions," Criminology 35(1), 177-201.

Rutter, Michael, Patrick Bolton, Richard Harrington, Ann Le Couteur, Hope MacDonald and Emily Simonoff (1990), "Genetic Factors in Child Psychiatric Disorders: A Review of Research Strategies," Journal of Child Psychology \& Psychiatry \& Allied Disciplines. 31(1): 3-37.

Sarnecki, Jerzy (2003), Introduktion till Kriminologi (Introduction to Criminology), Studentliteratur.

Snell, Tracy (1993), "Correctional Populations in the United States, 1991," Washington, D.C.: U.S. Department of Justice.

Solon, Gary (1992) "Intergenerational Income Mobility in the United States," American Economic Review 82(3), 393-408.

Stenberg, Sten-Åke (2000), "Inheritance of Welfare Recipiency: An Intergenerational Study of Social Assistance Recipiency in Postwar Sweden," Journal of Marriage and the Family 62(1), 228-39. 
Stenberg, Sten-Åke and Denny Vågerö (2006), "Cohort profile: The Stockholm Birth Cohort of 1953," International Journal of Epidemiology 35, 546-548.

Stenberg, Sten-Åke, Denny Vågerö, Reidar Österman, Emma Arvidsson, Cecelia Von Otter and Carl-Gunnar Janson (2007), "Stockholm Birth Cohort Study 1953-2003: A new tool for lifecourse studies," Scandinavian Journal of Public Health 35(1), 104-10.

Thornberry, Terence P. (2009), “The Apple Doesn't Fall Far from the Tree (or Does It?): Intergenerational Patterns of Anti-Social Behavior - The American Society of Criminology 2008 Sutherland Address," Criminology 47(2), 297-325.

Tillman, Robert (1987), “The Size of the 'Criminal Population': The Prevalence and Incidence of Adult Arrest," Criminology 25, 57-84.

van de Rakt, Marieke, Paul Nieuwbeerta and Robert Apel (2009) "Association of Criminal Convictions between Family Members: Effects of Siblings, Fathers and Mothers," Criminal Behaviour and Mental Health 19(2), 94-108.

Westfelt, Lisa (2001), "Brott och Straff i Sverige och Europa: En Studie I Komparativ Kriminologi" (Crime and Punishment in Sweden and Europe: A Study in Comparative Criminology), Department of Criminology, Stockholm University.

Williams, Jenny and Robin Sickles (2002), “An Analysis of the Crime as Work Model: Evidence from the 1958 Philadelphia Birth Cohort Study," The Journal of Human Resources. 37(3), 479509.

Wilson, Harriett (1987), "Parental Supervision Re-examined," British Journal of Criminology 27(3), 275-301.

Wolfgang, Marvin E., Robert M. Figlio and Thorsten Sellin (1972), Delinquency in a BirthCohort, Chicago: Chicago University Press. 
Table 1. Crime data for Sweden, the United States and Europe, 1950 - 2005.

\begin{tabular}{|c|c|c|c|c|c|c|c|c|}
\hline \multirow[b]{2}{*}{ Year } & \multicolumn{2}{|c|}{$\begin{array}{c}\text { Total criminal } \\
\text { offenses reported in } \\
\text { Sweden }^{\mathrm{a}}\end{array}$} & \multicolumn{3}{|c|}{$\begin{array}{c}\text { Intentional homicide, per } \\
100,000 \text { persons }\end{array}$} & \multicolumn{3}{|c|}{$\begin{array}{l}\text { Theft of Motor Vehicle, per } \\
100,000 \text { persons }\end{array}$} \\
\hline & $\begin{array}{c}\text { Per } \\
100,000 \\
\text { persons }\end{array}$ & Index & Sweden & U.S. ${ }^{b}$ & Europe $^{c}$ & Sweden & U.S. & Europe \\
\hline 1950 & 2784 & 100 & 1 & 5 &..$^{\mathrm{d}}$ & .. & $95^{\mathrm{e}}$ & .. \\
\hline 1955 & 3357 & 121 & 1 & 4 & .. & .. & $138^{\mathrm{e}}$ & .. \\
\hline 1960 & 3982 & 143 & 1 & 5 & .. & 244 & 183 & .. \\
\hline 1965 & 5801 & 208 & 3 & 5 & .. & 397 & 257 & .. \\
\hline 1970 & 8157 & 293 & 1 & 8 & .. & 402 & 457 & .. \\
\hline 1975 & 9221 & 331 & 1 & 10 & .. & 448 & 474 & .. \\
\hline 1980 & 11170 & 401 & 2 & 10 & .. & 413 & 502 & .. \\
\hline 1985 & 12195 & 438 & 2 & 8 & .. & 539 & 462 & \\
\hline 1990 & 14240 & 511 & 1 & 9 & 2.6 & 882 & 658 & 298 \\
\hline 1995 & 12982 & 466 & 2 & 8 & 3.4 & 659 & 560 & 310 \\
\hline 2000 & 13694 & 492 & 2 & 6 & 3 & 712 & 412 & 275 \\
\hline 2005 & 13753 & 494 & 3 & 6 & .. & 467 & 417 &.. \\
\hline
\end{tabular}

(a) All Swedish statistics were downloaded from the homepage of the Swedish National Council for Crime Prevention (BRÅ) on July 8, 2009, http://www.bra.se/extra/measurepoint/.../10La_anm2_fr1950.xls.

(b) U.S. statistics are from the FBI's Uniform Crime Reports.

(c) European statistics are from the European Sourcebook of Crime and Criminal Justice Statistics (1996, 2003). Figures for 1990 and 1995 are averages across 36 European countries (including Sweden). Figures for 2000 are averages across 40 European countries (including Sweden).

(d) ".." indicates that the data is unavailable.

(e) Authors' own calculations based on data taken from the FBI's Uniform Crime Reports. 
Table 2. Descriptive Statistics of Crime Variables

\begin{tabular}{|c|c|c|c|c|c|}
\hline \multirow[b]{2}{*}{ Variable } & \multirow[b]{2}{*}{ Definition } & \multicolumn{2}{|c|}{$\begin{array}{c}\text { Males } \\
(\mathrm{n}=7719)\end{array}$} & \multicolumn{2}{|c|}{$\begin{array}{l}\text { Females } \\
(\mathrm{n}=7398)\end{array}$} \\
\hline & & Mean & SD & Mean & SD \\
\hline \multicolumn{6}{|c|}{ Cohort Member Juvenile Delinquency Variables } \\
\hline Crime6072 & 1 if has record of any offense from $1960-72$ & 0.20 & 0.40 & 0.06 & 0.23 \\
\hline Steal6072 & $\begin{array}{l}1 \text { if was caught stealing, petty theft, motor vehicle } \\
\text { theft, burglary, and other theft from } 1960-72\end{array}$ & 0.16 & 0.36 & 0.04 & 0.20 \\
\hline Violent6072 & 1 if caught committing violent crime from $1960-72$ & 0.07 & 0.25 & 0.01 & 0.08 \\
\hline Narcotic6072 & 1 if commit alcohol or narcotics abuse from $1960-72$ & 0.04 & 0.19 & 0.02 & 0.15 \\
\hline Other6072 & 1 if other offense, driving and sex, from 1960-72 & 0.04 & 0.21 & 0.00 & 0.04 \\
\hline \multicolumn{6}{|c|}{ Cohort Member Adult Crime Variables - Extensive Margin } \\
\hline Crime & 1 if any crime in PBR through 1984 & 0.33 & 0.47 & 0.07 & 0.26 \\
\hline Violent & 1 if violent crime in PBR through 1984 & 0.08 & 0.27 & 0.01 & 0.10 \\
\hline Steal & 1 if theft in PBR through 1984 & 0.19 & 0.39 & 0.04 & 0.21 \\
\hline Fraud & 1 if fraud offense in PBR through 1984 & 0.06 & 0.24 & 0.02 & 0.13 \\
\hline Traffic & 1 if traffic offense in PBR through 1984 & 0.15 & 0.36 & 0.01 & 0.11 \\
\hline Narcotic & 1 if narcotic offense in PBR through 1984 & 0.04 & 0.20 & 0.01 & 0.10 \\
\hline Vandalism & 1 if vandalism offense in PBR through 1984 & 0.06 & 0.24 & 0.00 & 0.06 \\
\hline Other & 1 if other offense in PBR through 1984 & 0.13 & 0.34 & 0.01 & 0.10 \\
\hline \multicolumn{6}{|c|}{ Cohort Member Adult Crime Variables - Intensive Margin } \\
\hline CrimeSum & Number of crimes in PBR through 1984 & 3.43 & 15.35 & 0.40 & 4.01 \\
\hline ViolentSum & Number of violent crimes in PBR through 1984 & 0.21 & 1.21 & 0.02 & 0.25 \\
\hline StealSum & Number of thefts in PBR through 1984 & 1.60 & 9.97 & 0.14 & 1.16 \\
\hline FraudSum & Number of fraud offenses in PBR through 1984 & 0.27 & 2.10 & 0.10 & 1.14 \\
\hline TrafficSum & Number off traffic offenses in PBR through 1984 & 0.10 & 0.59 & 0.01 & 0.11 \\
\hline NarcoticSum & Number of narcotic offenses in PBR through 1984 & 0.65 & 4.16 & 0.07 & 1.69 \\
\hline VandalismSum & Number of vandalism offenses in PBR through 1984 & 0.20 & 1.56 & 0.04 & 0.59 \\
\hline OtherSum & Number of other offenses in PBR through 1984 & 0.39 & 1.75 & 0.03 & 0.69 \\
\hline \multicolumn{6}{|c|}{ Father Crime Variables - Extensive Margin } \\
\hline Father & 1 if father has at least one sentence & 0.12 & 0.32 & 0.13 & 0.33 \\
\hline ProbationFather & 1 if father has at least one probation sentence & 0.08 & 0.28 & 0.09 & 0.28 \\
\hline PrisonFather & 1 if father has at least one prison sentence & 0.03 & 0.18 & 0.04 & 0.19 \\
\hline DrivingFather & 1 if father has at least one drunk driving sentence & 0.04 & 0.18 & 0.04 & 0.21 \\
\hline ExemptFather & 1 if father has at least one exempt sentence & 0.01 & 0.07 & 0.00 & 0.07 \\
\hline \multicolumn{6}{|c|}{ Father Crime Variables - Intensive Margin } \\
\hline FatherSum & Total number of father's sentences & 0.25 & 1.09 & 0.28 & 1.10 \\
\hline ProbationFatherSum & Number of times father sentenced to probation & 0.12 & 0.46 & 0.13 & 0.50 \\
\hline PrisonFatherSum & Number of times father sentenced to prison & 0.08 & 0.63 & 0.08 & 0.61 \\
\hline DrivingFatherSum & $\begin{array}{l}\text { Number of times father received drunk driving } \\
\text { sentence }\end{array}$ & 0.05 & 0.31 & 0.06 & 0.35 \\
\hline ExemptFatherSum & Number of times father received exempt sentence & 0.01 & 0.14 & 0.01 & 0.12 \\
\hline
\end{tabular}


Table 3. Crime Statistics for Cohort Members by Fathers Criminality

\begin{tabular}{lcc}
\hline & $\begin{array}{c}\text { Father has a } \\
\text { record } \\
\text { (Father = 1) }\end{array}$ & $\begin{array}{c}\text { Father does not have a } \\
\text { record } \\
\text { (Father = 0) }\end{array}$ \\
\hline \% of sons with an adult record & $48.4 \%$ & $31.2 \%$ \\
\% of daughters with an adult record & 918 & 6801 \\
Average \# of crimes committed by sons & $14.3 \%$ & $5.9 \%$ \\
Average \# of crimes committed by & 949 & 6449 \\
daughters & 6.75 & 2.98 \\
\hline Sang & 918 & 6801 \\
\hline
\end{tabular}

Sample sizes in italics. 
Table 4. Raw Extensive Margin Odds Ratios for Sons and Daughters

\begin{tabular}{|c|c|c|c|c|c|c|c|c|}
\hline & $\begin{array}{l}(1) \\
\text { crime }\end{array}$ & $\begin{array}{c}(2) \\
\text { violent }\end{array}$ & $\begin{array}{c}(3) \\
\text { steal }\end{array}$ & $\begin{array}{l}(4) \\
\text { fraud }\end{array}$ & $\begin{array}{c}(5) \\
\text { vandalism }\end{array}$ & $\begin{array}{c}(6) \\
\text { traffic }\end{array}$ & $\begin{array}{c}(7) \\
\text { narcotic }\end{array}$ & $\begin{array}{c}(8) \\
\text { other }\end{array}$ \\
\hline \multicolumn{9}{|c|}{ Panel A: Father has any Sentence } \\
\hline Father & $2.064^{* *}$ & $2.481 * *$ & $2.267 * *$ & $2.160 * *$ & $2.170^{* *}$ & $1.861^{* *}$ & $1.981 * *$ & $1.990 * *$ \\
\hline Father*Daughter & $1.287^{*}$ & 1.216 & $1.352^{*}$ & $1.628 *$ & 0.754 & 1.468 & $1.964 *$ & 1.451 \\
\hline Daughter & $0.139^{* *}$ & $0.119^{* *}$ & $0.176^{* *}$ & $0.245^{* *}$ & $0.071^{* *}$ & $0.067 * *$ & $0.190^{* *}$ & $0.063^{* *}$ \\
\hline \multicolumn{9}{|c|}{ Panel B: Father has Probation Sentence } \\
\hline ProbationFather & $2.234 * *$ & $2.560^{* *}$ & $2.434 * *$ & $2.451 * *$ & $2.175^{* *}$ & $1.993^{* *}$ & $2.201 * *$ & $2.048 * *$ \\
\hline ProbationFather*Daughter & 1.159 & 0.76 & 1.273 & 1.539 & 0.735 & 0.976 & 1.283 & 0.965 \\
\hline Daughter & $0.145^{* *}$ & $0.133^{* *}$ & $0.184 * *$ & $0.258^{* *}$ & $0.070 * *$ & $0.074 * *$ & $0.222 * *$ & $0.070 * *$ \\
\hline \multicolumn{9}{|c|}{ Panel C: Father has Prison Sentence } \\
\hline PrisonFather & $2.162 * *$ & $2.101^{* *}$ & $2.307 * *$ & $2.228 * *$ & $2.083^{* *}$ & $2.165^{* *}$ & $1.770 *$ & $2.083 * *$ \\
\hline PrisonFather*Daughter & 1.165 & 1.669 & 1.151 & 1.314 & 0.884 & 1.099 & 2.009 & 1.078 \\
\hline Daughter & $0.148^{* *}$ & $0.122 * *$ & $0.191 * *$ & $0.276^{* *}$ & $0.068 * *$ & $0.073 * *$ & $0.219^{* *}$ & $0.069^{* *}$ \\
\hline \multicolumn{9}{|c|}{ Panel D: Father has Drunk and Dangerous Driving Sentence } \\
\hline DrivingFather & $1.985^{* *}$ & $2.913 * *$ & $2.163^{* *}$ & $1.809 * *$ & $2.856^{* *}$ & $1.730 * *$ & $2.215^{* *}$ & $2.150 * *$ \\
\hline DrivingFather*Daughter & 1.472 & 1.354 & 1.268 & 1.895 & 0.518 & $2.674 * *$ & $2.817 * *$ & 1.862 \\
\hline Daughter & $0.144 * *$ & $0.120^{* *}$ & $0.188^{* *}$ & $0.264 * *$ & $0.070 * *$ & $0.066 * *$ & $0.198 * *$ & $0.064 * *$ \\
\hline \multicolumn{9}{|c|}{ Panel E: Father has Exempt Sentence } \\
\hline ExemptFather & $2.116^{*}$ & $3.875^{* *}$ & 1.547 & $5.015^{* *}$ & 2.241 & 1.543 & 2.385 & 0.914 \\
\hline ExemptFather*Daughter & 1.355 & 0.731 & 1.873 & 0.678 & 3.305 & $4.750^{*}$ & 3.945 & 3.139 \\
\hline Daughter & $0.151^{* *}$ & $0.129 * *$ & $0.194 * *$ & $0.286^{* *}$ & $0.066^{* *}$ & $0.072 * *$ & $0.227 * *$ & $0.070^{* *}$ \\
\hline Observations & 15118 & 15118 & 15118 & 15118 & 15118 & 15118 & 15118 & 15118 \\
\hline
\end{tabular}


Table 5. Raw Intensive Margin Incidence Rate Ratios for Sons and Daughters

\begin{tabular}{|c|c|c|c|c|c|c|c|c|}
\hline & $\begin{array}{c}(1) \\
\text { crimesum } \\
\end{array}$ & $\begin{array}{c}(2) \\
\text { violentsum } \\
\end{array}$ & $\begin{array}{c}(3) \\
\text { stealsum }\end{array}$ & $\begin{array}{c}(4) \\
\text { fraudsum }\end{array}$ & $\begin{array}{c}(5) \\
\text { vandalismsum } \\
\end{array}$ & $\begin{array}{c}(6) \\
\text { trafficsum } \\
\end{array}$ & $\begin{array}{c}(7) \\
\text { narcoticsum } \\
\end{array}$ & $\begin{array}{c}\text { (8) } \\
\text { othersum }\end{array}$ \\
\hline \multicolumn{9}{|c|}{ Panel A: Number of Father Sentences } \\
\hline FatherSum & $1.324 * *$ & $1.404 * *$ & $1.320 * *$ & $1.255^{* *}$ & $1.332 * *$ & $1.322 * *$ & $1.329 * *$ & $1.307 * *$ \\
\hline FatherSum*Daughter & 1.144 & 0.975 & $1.239 *$ & 1.174 & 0.825 & 1.092 & 1.192 & 0.965 \\
\hline Daughter & $0.106 * *$ & $0.096 * *$ & $0.074 * *$ & $0.332 * *$ & $0.062 * *$ & $0.095 * *$ & $0.175 * *$ & $0.079 * *$ \\
\hline \multicolumn{9}{|c|}{ Panel B: Number of Father Probation Sentences } \\
\hline ProbationFathersum & $1.680 * *$ & $1.850 * *$ & $1.527 * *$ & $1.852 * *$ & $1.588 * *$ & $1.888 * *$ & $1.688 * *$ & $1.637 * *$ \\
\hline ProbationFathersum* Daughter & 1.048 & 0.896 & $1.496^{*}$ & 1.007 & 0.82 & $0.516^{*}$ & 1.029 & 0.808 \\
\hline Daughter & $0.113 * *$ & $0.098 * *$ & $0.074 * *$ & $0.358 * *$ & $0.059 * *$ & $0.117 * *$ & $0.192 * *$ & $0.082 * *$ \\
\hline \multicolumn{9}{|c|}{ Panel C: Number of Father Prison Sentences } \\
\hline PrisonFatherSum & $1.250 * *$ & $1.244^{*}$ & $1.201 *$ & $1.295^{* *}$ & $1.225^{*}$ & $1.327 * *$ & $1.275^{*}$ & $1.199 * *$ \\
\hline PrisonFatherSum* Daughter & 1.341 & 1.052 & 1.284 & 1.348 & 0.696 & 1.528 & 1.263 & 0.991 \\
\hline Daughter & $0.111 * *$ & $0.098 * *$ & $0.083 * *$ & $0.352 * *$ & $0.059 * *$ & $0.092 * *$ & $0.191 * *$ & $0.079 * *$ \\
\hline \multicolumn{9}{|c|}{ Panel D: Number of Father Drunk and Dangerous Driving Sentences } \\
\hline DrivingFatherSum & $2.043 * *$ & $1.910^{* *}$ & $2.328 * *$ & 1.299 & $2.400 * *$ & $1.882 * *$ & $1.732 * *$ & $1.854 * *$ \\
\hline DrivingFatherSum* Daughter & 1.462 & 1.126 & 1.374 & $2.003 *$ & 0.552 & 1.799 & 1.994 & 1.167 \\
\hline Daughter & $0.108 * *$ & $0.095 * *$ & $0.081 * *$ & $0.330 * *$ & $0.061 * *$ & $0.088 * *$ & $0.173 * *$ & $0.076 * *$ \\
\hline \multicolumn{9}{|c|}{ Panel E: Number of Father Exempt Sentences } \\
\hline ExemptFatherSum & $2.219 *$ & $1.805^{*}$ & 1.353 & $3.657 * *$ & 1.592 & $3.810 * *$ & 1.438 & 2.528 \\
\hline ExemptFatherSum * Daughter & 1.311 & 2.043 & 2.487 & 0.383 & 1.681 & 0.682 & 2.569 & 1.281 \\
\hline Daughter & $0.116^{* *}$ & $0.095 * *$ & $0.085^{* * *}$ & $0.379 * *$ & $0.057 * *$ & $0.105 * *$ & $0.192 * *$ & $0.078 * *$ \\
\hline Observations & 15118 & 15118 & 15118 & 15118 & 15118 & 15118 & 15118 & 15118 \\
\hline
\end{tabular}


Table 6. Odds Ratios between Fathers' Criminality and Juveniles' Delinquent Behavior at the Extensive Margin

\begin{tabular}{lccc|ccccc}
\hline & $(1)$ & $(2)$ & $(3)$ & $(4)$ & $(5)$ & $(6)$ & $(7)$ & $(8)$ \\
& \multicolumn{3}{c}{ Ages 7-12 } & & & & Ages 13-19 & \\
& & & & & & Narcotic/ \\
& Crime & Steal & Violent & Crime & Steal & Violent & Alcohol & Other \\
\hline Father & $2.514^{* *}$ & $2.508^{* *}$ & $2.838^{* *}$ & $2.146^{* *}$ & $2.230^{* *}$ & $2.572^{* *}$ & $1.810^{* *}$ & $1.811^{* *}$ \\
Father*Daughter & 1.369 & 1.284 & 4.808 & $1.536^{* *}$ & $1.639^{* *}$ & 0.718 & $1.760^{*}$ & 1.368 \\
Daughter & $0.164^{* *}$ & $0.208^{* *}$ & $0.026^{* *}$ & $0.206^{* *}$ & $0.176^{* *}$ & $0.106^{* *}$ & $0.516^{* *}$ & $0.040^{* *}$ \\
\hline Observations & 15118 & 15118 & 15118 & 15118 & 15118 & 15118 & 15118 & 15118 \\
\hline
\end{tabular}

* significant at 5\%; ** significant at 1\%. This table presents the results of logistic regressions where the dependent variable is listed in the top of column. Each regression includes three variables: some measure of father criminality, an indicator for whether the cohort member is female, and an interaction between the two. Odds ratios are presented. The odds ratio associated with the father criminality variable can be interpreted as the odds that sons are convicted of a crime if they have a criminal father. The coefficient on the interaction indicates whether the effect of fathers on their daughters significantly differs from the effect on their sons. 
Table 7. Explaining the Relationship Between Father and Child Criminality at the Extensive and Intensive Margin

(1)

(2)

Panel A: Extensive Margin for Sons

\begin{tabular}{lccccccc} 
Father & $2.064^{* *}$ & $1.680^{* *}$ & $1.492^{* *}$ & $1.308^{* *}$ & $1.211^{*}$ & $1.217^{*}$ & $1.288^{* *}$ \\
& {$[0.147]$} & {$[0.123]$} & {$[0.113]$} & {$[0.104]$} & {$[0.099]$} & {$[0.100]$} & {$[0.116]$} \\
Sample Size & 7719 & 7719 & 7719 & 7719 & 7719 & 7719 & 7335 \\
\hline
\end{tabular}

Panel B: Extensive Margin for Daughters

\begin{tabular}{lccccccc} 
Father & $2.657^{* *}$ & $2.272^{* *}$ & $1.995^{* *}$ & $1.641^{* *}$ & $1.530^{* *}$ & $1.492^{* *}$ & $1.570^{* *}$ \\
Sample Size & {$[0.283]$} & {$[0.258]$} & {$[0.227]$} & {$[0.201]$} & {$[0.191]$} & {$[0.187]$} & {$[0.213]$} \\
& 7399 & 7398 & 7398 & 7398 & 7398 & 7398 & 5385 \\
\hline \multicolumn{7}{c}{ Panel C: Intensive Margin for Sons } \\
FatherSum & $1.323^{* *}$ & $1.210^{* *}$ & $1.133^{* *}$ & $1.070^{* *}$ & 1.036 & 1.03 & $1.059^{*}$ \\
& {$[0.061]$} & {$[0.047]$} & {$[0.033]$} & {$[0.026]$} & {$[0.023]$} & {$[0.021]$} & {$[0.024]$} \\
Sample Size & 7719 & 7719 & 7719 & 7719 & 7719 & 7719 & 7717 \\
\hline
\end{tabular}

Panel D:Intensive Margin for Daughters

\begin{tabular}{lccccccc} 
FatherSum & $1.526^{* *}$ & $1.513^{* *}$ & $1.409^{* *}$ & $1.354^{* *}$ & $1.345^{* *}$ & $1.225^{* *}$ & \\
& {$[0.130]$} & {$[0.129]$} & {$[0.104]$} & {$[0.108]$} & {$[0.112]$} & {$[0.086]$} & \\
Sample Size & 7399 & 7398 & 7398 & 7398 & 7398 & 7398 & \\
\hline Controls for: & & & & & & & \\
SES & NO & YES & YES & YES & YES & YES & YES \\
Ability & NO & NO & YES & YES & YES & YES & YES \\
Unstable Household & NO & NO & NO & YES & YES & YES & YES \\
Social Support & NO & NO & NO & NO & YES & YES & YES \\
Household Attitudes & NO & NO & NO & NO & NO & YES & YES \\
Neighborhood Fixed & NO & NO & NO & NO & NO & NO & YES \\
Effects & & & &
\end{tabular}

Standard errors in parentheses. * significant at 5\%; ** significant at 1\%. Extensive margin specifications (Panels A and B) estimate logit regressions and present odds ratios while intensive margin specifications (Panels C and D) estimate negative binomial regressions and present incident rate ratios. SES controls include a set of dummy variables capturing father's social class in both 1953 and 1963, whether the father is Swedish, whether the father is employed in 1960, father's net income in 1963, and four dummy variables indicating whether the father and mother have a high school education or college. Ability controls for both sons and daughters include verbal, spatial, and math tests scores on a $6^{\text {th }}$ grade IQ test and $6^{\text {th }}$ grade marks. Additional cognitive (instructions, verbal, spatial, and technical) and non-cognitive (psychological assessment) ability controls are included for sons and obtained from the tests upon entering the military draft. Unstable household controls include measures of parental alcoholism, drunkenness, mental illness and death from 1953 to 1972. Two social support variables are included - whether they received any support and the number of years of support from 1953 to 1972. Household attitudes include indicators for whether the child was absent from school when not sick and whether their parent allowed them to smoke. Missing observations are replaced with the variable mean and dummy variables indicating that the observations are missing are included but not presented in the above table. Note that the sample size decreases when neighborhood fixed effects are included because some neighborhoods have so few people included that the neighborhood is a perfect predictor of cohort member criminality; these individuals get dropped from the analysis. In addition, the negative binomial model for daughters with neighborhood fixed effects does not converge. 
Table 8. Explaining the Father-Son Crime Relationship by Crime Type

\begin{tabular}{|c|c|c|c|c|c|c|c|c|c|c|c|c|c|c|c|c|c|c|}
\hline & (1) & $\begin{array}{l}(2) \\
\text { Violent }\end{array}$ & (3) & (4) & $\begin{array}{c}(5) \\
\text { Steal }\end{array}$ & (6) & (7) & $\begin{array}{l}(8) \\
\text { Fraud }\end{array}$ & (9) & $(10)$ & $\begin{array}{c}(11) \\
\text { Vandalism }\end{array}$ & (12) & (13) & $\begin{array}{l}(14) \\
\text { Traffic }\end{array}$ & (15) & (16) & $\begin{array}{c}(17) \\
\text { Narcotic }\end{array}$ & (18) \\
\hline \multicolumn{19}{|l|}{ Extensive Margin } \\
\hline Father & $\begin{array}{c}2.481 * * \\
{[0.257]}\end{array}$ & $\begin{array}{l}1.601 * * \\
{[0.179]}\end{array}$ & $\begin{array}{c}1.239 \\
{[0.153]}\end{array}$ & $\begin{array}{c}2.267^{* *} \\
{[0.176]}\end{array}$ & $\begin{array}{l}1.582^{* *} \\
{[0.131]}\end{array}$ & $\begin{array}{l}1.282^{* *} \\
{[0.116]}\end{array}$ & $\begin{array}{c}2.160^{* * *} \\
{[0.254]}\end{array}$ & $\begin{array}{l}1.464 * * \\
{[0.185]}\end{array}$ & $\begin{array}{c}1.164 \\
{[0.166]}\end{array}$ & $\begin{array}{c}2.170^{* *} \\
{[0.260]}\end{array}$ & $\begin{array}{l}1.511 * * \\
{[0.190]}\end{array}$ & $\begin{array}{c}1.114 \\
{[0.162]}\end{array}$ & $\begin{array}{c}1.861^{* *} \\
{[0.158]}\end{array}$ & $\begin{array}{l}1.390^{* * *} \\
{[0.124]}\end{array}$ & $\begin{array}{c}1.176 \\
{[0.114]}\end{array}$ & $\begin{array}{l}1.981 * * \\
{[0.277]}\end{array}$ & $\begin{array}{c}1.302 \\
{[0.195]}\end{array}$ & $\begin{array}{c}1.025 \\
{[0.177]}\end{array}$ \\
\hline \multicolumn{19}{|l|}{ Intensive Margin } \\
\hline Fathersum & $\begin{array}{c}1.401 * * \\
{[0.102]}\end{array}$ & $\begin{array}{l}1.096^{*} \\
{[0.040]}\end{array}$ & $\begin{array}{c}1.023 \\
{[0.029]}\end{array}$ & $\begin{array}{l}1.319^{* *} \\
{[0.090]}\end{array}$ & $\begin{array}{l}1.129 * * \\
{[0.039]}\end{array}$ & $\begin{array}{c}1.019 \\
{[0.027]}\end{array}$ & $\begin{array}{c}1.253^{* *} \\
{[0.079]}\end{array}$ & $\begin{array}{l}1.099 * \\
{[0.047]}\end{array}$ & $\begin{array}{c}1.02 \\
{[0.030]}\end{array}$ & $\begin{array}{c}1.330^{* * *} \\
{[0.076]}\end{array}$ & $\begin{array}{l}1.118^{*} \\
{[0.048]}\end{array}$ & $\begin{array}{c}1.023 \\
{[0.042]}\end{array}$ & $\begin{array}{c}1.321^{* *} \\
{[0.075]}\end{array}$ & $\begin{array}{l}1.130 \text { ** } \\
{[0.044]}\end{array}$ & $\begin{array}{c}1.035 \\
{[0.025]}\end{array}$ & $\begin{array}{c}1.328^{* *} \\
{[0.092]}\end{array}$ & $\begin{array}{l}1.155^{*} \\
{[0.080]}\end{array}$ & $\begin{array}{c}1.095 \\
{[0.081]}\end{array}$ \\
\hline No Controls & YES & NO & NO & YES & $\mathrm{NO}$ & NO & YES & NO & NO & YES & NO & NO & YES & NO & $\mathrm{NO}$ & YES & NO & NO \\
\hline $\begin{array}{l}\text { SES and Ability } \\
\text { Controls }\end{array}$ & NO & YES & $\mathrm{NO}$ & NO & YES & NO & NO & YES & NO & NO & YES & NO & NO & YES & NO & NO & YES & NO \\
\hline All Controls & NO & NO & YES & NO & NO & YES & NO & NO & YES & NO & $\mathrm{NO}$ & YES & $\mathrm{NO}$ & NO & YES & NO & NO & YES \\
\hline
\end{tabular}

Robust standard errors in brackets. * significant at 5\%; ** significant at 1\%. Each cell presents the coefficient associated with a father criminality from a separate specification. The dependent variable is either

the number of crimes committed by the cohort member in a particular crime category or whether the cohort member committed any crimes in that category; i.e. the intensive and extensive margins respectively.

Extensive margin specifications are estimated with a logit model and presents odds ratios while intensive margin specifications are estimated with a negative binomial model and presents incidence rate ratios.

Missing observations are replaced with the variable mean and dummy variables indicating that the observations are missing are included but not presented in the above table. 
Table 9. Sibling Correlations in Crime at the Extensive and Intensive Margins

Extensive margin

Intensive margin

Twin Pair types

$\mathrm{MZ}$ MZDZ

DZ

MZ

MZDZ

All

DZ

\section{Crime}

\begin{tabular}{|c|c|c|c|c|c|c|c|c|}
\hline Male + Female & $\begin{array}{l}0.475^{* *} \\
(0.2043)\end{array}$ & $\begin{array}{l}0.471^{* * *} \\
(0.1666)\end{array}$ & $\begin{array}{l}0.364^{* * *} \\
(0.0954)\end{array}$ & $\begin{array}{c}0.297^{* *} \\
(0.1412)\end{array}$ & $\begin{array}{c}0.316 \\
(0.1988)\end{array}$ & $\begin{array}{l}0.985^{* * *} \\
(0.3118)\end{array}$ & $\begin{array}{c}0.332 \\
(0.2337)\end{array}$ & $\begin{array}{c}0.044 \\
(0.1527)\end{array}$ \\
\hline Male & $\begin{array}{c}0.339 \\
(0.2463)\end{array}$ & $\begin{array}{l}0.333^{* *} \\
(0.1426)\end{array}$ & $\begin{array}{l}0.476^{* * *} \\
(0.1112)\end{array}$ & $\begin{array}{c}0.627^{* *} \\
(0.1860)\end{array}$ & $\begin{array}{c}0.208 \\
(0.2389)\end{array}$ & $\begin{array}{c}0.987^{* *} \\
(0.4221)\end{array}$ & $\begin{array}{c}0.632^{* *} \\
(0.2689)\end{array}$ & $\begin{array}{c}0.183 \\
(0.3626)\end{array}$ \\
\hline & \multicolumn{8}{|c|}{ Steal } \\
\hline Male + Female & $\begin{array}{c}0.377 \\
(0.2359)\end{array}$ & $\begin{array}{l}0.679^{* * *} \\
(0.1859)\end{array}$ & $\begin{array}{c}0.3192^{* * *} \\
(0.1118)\end{array}$ & $\begin{array}{c}0.224 \\
(0.1516)\end{array}$ & $\begin{array}{c}0.472 \\
(0.3520)\end{array}$ & $\begin{array}{l}0.999^{* * *} \\
(0.0004)\end{array}$ & $\begin{array}{c}0.238 \\
(0.2130)\end{array}$ & $\begin{array}{c}0.004 \\
(0.1101)\end{array}$ \\
\hline \multirow[t]{2}{*}{ Male } & $\begin{array}{c}0.342 \\
(0.2705)\end{array}$ & $\begin{array}{l}0.655^{\text {*** }} \\
(0.2108)\end{array}$ & $\begin{array}{c}0.430^{* *} \\
(0.1482)\end{array}$ & $\begin{array}{c}0.447 \\
(0.2492)\end{array}$ & $\begin{array}{c}0.437 \\
(0.4055)\end{array}$ & $\begin{array}{l}0.999^{* * *} \\
(0.0003)\end{array}$ & $\begin{array}{c}0.432 \\
(0.2764)\end{array}$ & $\begin{array}{c}0.030 \\
(0.3534)\end{array}$ \\
\hline & \multicolumn{8}{|c|}{ Traffic } \\
\hline Male + Female & $\begin{array}{l}0.849^{\gg \gg} \\
(0.1356)\end{array}$ & $\begin{array}{l}0.531^{* * *} \\
(0.1702)\end{array}$ & $\begin{array}{l}0.456^{* * *} \\
(0.1108)\end{array}$ & $\begin{array}{c}0.250 \\
(0.1827)\end{array}$ & $\begin{array}{l}0.755^{\gg \gg} \\
(0.1404)\end{array}$ & $\begin{array}{l}0.963^{* * *} \\
(0.0179)\end{array}$ & $\begin{array}{c}0.231 \\
(0.1907)\end{array}$ & $\begin{array}{c}0.050 \\
(0.1533)\end{array}$ \\
\hline Male & $\begin{array}{c}0.829^{\gg>} \\
(0.1596)\end{array}$ & $\begin{array}{c}0.488^{* *} \\
(0.2135)\end{array}$ & $\begin{array}{l}0.495^{* * *} \\
(0.1569)\end{array}$ & $\begin{array}{c}0.294 \\
(0.2250)\end{array}$ & $\begin{array}{c}0.710^{>} \\
(0.1464)\end{array}$ & $\begin{array}{l}0.965^{\text {*** }} \\
(.01478)\end{array}$ & $\begin{array}{l}0.565^{* * *} \\
(0.1776)\end{array}$ & $\begin{array}{c}0.192 \\
(0.2727)\end{array}$ \\
\hline
\end{tabular}

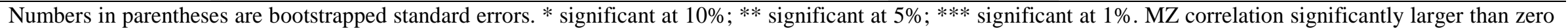
and significantly larger than DZ correlation at $\gg>1 \%,>>5 \%,>10 \%$. MZ = monozygotic, DZ = dizygotic, MZDZ $=$ unknown zygosity. 
Table 10. Adoption and Intergenerational Criminal Correlations at the Extensive and Intensive Margins

\begin{tabular}{|c|c|c|c|c|c|c|}
\hline & (1) & $\begin{array}{c}(2) \\
\text { Sons }\end{array}$ & (3) & (4) & $\begin{array}{c}(5) \\
\text { Daughters }\end{array}$ & (6) \\
\hline \multicolumn{7}{|l|}{ Extensive Margin } \\
\hline Father & $\begin{array}{c}2.064 * * \\
{[0.147]}\end{array}$ & $\begin{array}{l}2.072^{* *} \\
{[0.148]}\end{array}$ & $\begin{array}{l}1.221^{*} \\
{[0.100]}\end{array}$ & $\begin{array}{c}2.657^{* *} \\
{[0.283]}\end{array}$ & $\begin{array}{l}2.730^{* *} \\
{[0.295]}\end{array}$ & $\begin{array}{l}1.519 * * \\
{[0.194]}\end{array}$ \\
\hline Adopt & & $\begin{array}{c}1.19 \\
{[0.251]}\end{array}$ & $\begin{array}{c}1.178 \\
{[0.267]}\end{array}$ & & $\begin{array}{l}2.103^{*} \\
{[0.630]}\end{array}$ & $\begin{array}{c}2.375 * * \\
{[0.718]}\end{array}$ \\
\hline Father*Adopt & & $\begin{array}{c}0.747 \\
{[0.482]}\end{array}$ & $\begin{array}{c}0.729 \\
{[0.559]}\end{array}$ & & $\begin{array}{c}0.338 \\
{[0.232]}\end{array}$ & $\begin{array}{c}0.4 \\
{[0.285]}\end{array}$ \\
\hline \multicolumn{7}{|l|}{ Intensive Margin } \\
\hline FatherSum & $\begin{array}{l}1.323^{* *} \\
{[0.061]}\end{array}$ & $\begin{array}{l}1.339 * * \\
{[0.063]}\end{array}$ & $\begin{array}{c}1.026 \\
{[0.021]}\end{array}$ & $\begin{array}{l}1.526^{* *} \\
{[0.130]}\end{array}$ & $\begin{array}{l}1.574 * * \\
{[0.134]}\end{array}$ & $\begin{array}{l}1.247 * * \\
{[0.087]}\end{array}$ \\
\hline Adopt & & $\begin{array}{l}3.951 * * \\
{[1.556]}\end{array}$ & $\begin{array}{l}2.313^{*} \\
{[0.792]}\end{array}$ & & $\begin{array}{l}7.604 * * \\
{[4.973]}\end{array}$ & $\begin{array}{l}6.258 * * \\
{[2.984]}\end{array}$ \\
\hline FatherSum*Adopt & & $\begin{array}{c}0.616 \\
{[0.244]}\end{array}$ & $\begin{array}{c}1.082 \\
{[0.470]}\end{array}$ & & $\begin{array}{l}0.422^{*} \\
{[0.172]}\end{array}$ & $\begin{array}{l}0.478^{*} \\
{[0.169]} \\
\end{array}$ \\
\hline Controls? & NO & NO & YES & NO & NO & YES \\
\hline Observations & 7719 & 7719 & 7719 & 7399 & 7399 & 7398 \\
\hline
\end{tabular}


Table 11. Timing of Father Criminality

\begin{tabular}{|c|c|c|c|c|c|c|}
\hline & $\begin{array}{l}(1) \\
\text { Depen } \\
\text { Crime }\end{array}$ & $\begin{array}{l}\text { (2) } \\
\text { ariable: } \\
\text { uvenile }\end{array}$ & \multicolumn{4}{|c|}{ Dependent Variable: Crime as an Adult } \\
\hline & \multicolumn{2}{|c|}{ Extensive Margin } & \multicolumn{2}{|c|}{ Extensive Margin } & \multicolumn{2}{|c|}{ Intensive Margin } \\
\hline $\begin{array}{l}\text { Father crime in pre- and post- } 1953 \\
\text { periods }\end{array}$ & $\begin{array}{l}3.807 * * \\
{[0.673]}\end{array}$ & $\begin{array}{l}4.069 * * \\
{[0.889]}\end{array}$ & $\begin{array}{l}3.777 * * \\
{[0.686]}\end{array}$ & $\begin{array}{l}3.683 * * \\
{[0.748]}\end{array}$ & $\begin{array}{l}1.230 * * \\
{[0.060]}\end{array}$ & $\begin{array}{l}1.370 * * \\
{[0.113]}\end{array}$ \\
\hline Father crime post- 1953 only & $\begin{array}{r}2.247 * * \\
{[0.236]} \\
\end{array}$ & $\begin{array}{l}3.275^{* *} \\
{[0.488]} \\
\end{array}$ & $\begin{array}{l}2.024 * * \\
{[0.199]}\end{array}$ & $\begin{array}{l}2.549 * * \\
{[0.366]} \\
\end{array}$ & $\begin{array}{l}1.498 * * \\
{[0.116]}\end{array}$ & $\begin{array}{l}1.895 * * \\
{[0.282]}\end{array}$ \\
\hline $\begin{array}{l}\text { Wald Test for H0: pre- } 1953 \text { only = post- } \\
1953 \text { only (p-value) } \\
\text { Sample } \\
\text { Observations }\end{array}$ & $\begin{array}{l}0.0133 \\
\text { Male } \\
7719\end{array}$ & $\begin{array}{c}0.4411 \\
\text { Female } \\
7399\end{array}$ & $\begin{array}{l}0.1928 \\
\text { Male } \\
7719\end{array}$ & $\begin{array}{c}0.6277 \\
\text { Female } \\
7399\end{array}$ & $\begin{array}{l}0.0684 \\
\text { Male } \\
7719\end{array}$ & $\begin{array}{c}0.0254 \\
\text { Female } \\
7399\end{array}$ \\
\hline
\end{tabular}

Robust standard errors in brackets. * significant at 5\%;** significant at 1\%. Extensive margin specifications are estimated with a logit model and odds ratios are presented. Intensive margin specifications are estimated with a negative binomial model and incident rate ratios are presented. No additional controls are included. 
Table 12. Quality of the Father - Child Relationship

(3)

Dependent Variable: Crime as a Juvenile

Father crime

Closeness

Father crime* ${ }^{*}$ Closeness

Sample

Observations

$1.649^{* *}$
$[0.4243]$
$0.407^{* * *}$
$[.0585]$
$1.966^{* *}$
$[0.6826]$

$1.649^{* * \cdots}$

[0.4013]

Male

1636

$$
\begin{aligned}
& 2.556^{* * *} \\
& {[0.7358]}
\end{aligned}
$$$$
1.953^{*}
$$$$
\text { [0.7012] }
$$$$
0.293^{* *}
$$$$
\text { [0.0854] }
$$$$
1.910
$$$$
\text { [1.1617] }
$$

\footnotetext{
Robust standard errors in brackets. * significant at $10 \%$; ** significant at

model. Odds ratios are presented. No additional controls are included.
} 
Table 13. Father Incarceration Effect

\begin{tabular}{|c|c|c|c|c|c|c|c|c|c|c|}
\hline $\begin{array}{l}\text { Dependent Variable } \\
\text { (Margin) }\end{array}$ & $\begin{array}{l}(1) \\
\text { juvenile } \\
\text { crime } \\
(\mathrm{ext})\end{array}$ & $\begin{array}{c}(2) \\
\text { Adult } \\
\text { crime } \\
(\text { ext })\end{array}$ & $\begin{array}{l}(3) \\
\text { Adult } \\
\text { crime } \\
(\mathrm{ext})\end{array}$ & $\begin{array}{l}(4) \\
\text { Adult } \\
\text { crime } \\
\text { (int) }\end{array}$ & $\begin{array}{l}(5) \\
\text { Adult } \\
\text { crime } \\
\text { (int) }\end{array}$ & $\begin{array}{l}(6) \\
\text { juvenile } \\
\text { crime } \\
\text { (ext) }\end{array}$ & $\begin{array}{l}(7) \\
\text { Adult } \\
\text { crime } \\
(\text { ext })\end{array}$ & $\begin{array}{l}(8) \\
\text { Adult } \\
\text { crime } \\
\text { (ext) }\end{array}$ & $\begin{array}{l}(9) \\
\text { Adult } \\
\text { crime } \\
\text { (int) }\end{array}$ & $\begin{array}{l}(10) \\
\text { Adult } \\
\text { crime } \\
\text { (int) }\end{array}$ \\
\hline fatherpost53 & $\begin{array}{c}2.405 * * * \\
{[0.250]}\end{array}$ & $\begin{array}{c}2.146 * * * \\
{[0.211]}\end{array}$ & & & & $\begin{array}{c}2.938 * * * \\
{[0.431]}\end{array}$ & $\begin{array}{c}2.575 * * * \\
{[0.353]}\end{array}$ & & & \\
\hline prisonfatherpost53 & $\begin{array}{c}1.167 \\
{[0.236]}\end{array}$ & $\begin{array}{c}1.267 \\
{[0.250]}\end{array}$ & & & & $\begin{array}{c}1.467 \\
{[0.374]}\end{array}$ & $\begin{array}{c}1.198 \\
{[0.304]}\end{array}$ & & & \\
\hline fathersumpost53 & & & $\begin{array}{c}1.421 * * * \\
{[0.081]}\end{array}$ & $\begin{array}{c}1.681 * * * \\
{[0.127]}\end{array}$ & $\begin{array}{l}1.724^{* * *} \\
{[0.137]}\end{array}$ & & & $\begin{array}{c}1.461 * * * \\
{[0.084]}\end{array}$ & $\begin{array}{c}2.245^{* * *} * \\
{[0.360]}\end{array}$ & $\begin{array}{l}2.176^{* * *} \\
{[0.360]}\end{array}$ \\
\hline prisonfathersumpost53 & & & $\begin{array}{c}0.719 * * * \\
{[0.073]}\end{array}$ & $\begin{array}{c}0.631 * * * \\
{[0.067]}\end{array}$ & $\begin{array}{c}0.74 \\
{[0.167]}\end{array}$ & & & $\begin{array}{c}0.711 * * * \\
{[0.077]}\end{array}$ & $\begin{array}{c}0.455^{* *} \\
{[0.139]}\end{array}$ & $\begin{array}{c}0.544 \\
{[0.205]}\end{array}$ \\
\hline Sample & Male & Male & Male & Male & Male & Female & Female & Female & Female & Female \\
\hline Observations & 7719 & 7719 & 7719 & 7719 & 7685 & 7399 & 7399 & 7399 & 7399 & 7389 \\
\hline
\end{tabular}


Appendix Table 1. Extensive Margin Regressions for Sons Displaying the Full Set of Controls

\begin{tabular}{|c|c|c|c|c|c|c|c|}
\hline & (1) & (2) & (3) & (4) & (5) & (6) & (7) \\
\hline father & $\begin{array}{c}2.064 * * \\
{[0.147]}\end{array}$ & $\begin{array}{l}1.680^{* *} \\
{[0.123]}\end{array}$ & $\begin{array}{l}1.492 * * \\
{[0.113]}\end{array}$ & $\begin{array}{l}1.308^{* *} \\
{[0.104]}\end{array}$ & $\begin{array}{l}1.211^{*} \\
{[0.099]}\end{array}$ & $\begin{array}{l}1.217^{*} \\
{[0.100]}\end{array}$ & $\begin{array}{l}1.288 * * \\
{[0.116]}\end{array}$ \\
\hline \multicolumn{8}{|c|}{ Father's Social Class 1953} \\
\hline lowerwhitecollar53 & & $\begin{array}{l}1.298^{*} \\
{[0.153]}\end{array}$ & $\begin{array}{c}1.269 \\
{[0.160]}\end{array}$ & $\begin{array}{c}1.269 \\
{[0.160]}\end{array}$ & $\begin{array}{c}1.25 \\
{[0.158]}\end{array}$ & $\begin{array}{c}1.275 \\
{[0.162]}\end{array}$ & $\begin{array}{c}1.272 \\
{[0.178]}\end{array}$ \\
\hline lowerentrepreneur53 & & $\begin{array}{c}1.195 \\
{[0.184]}\end{array}$ & $\begin{array}{c}1.111 \\
{[0.179]}\end{array}$ & $\begin{array}{c}1.098 \\
{[0.177]}\end{array}$ & $\begin{array}{c}1.088 \\
{[0.177]}\end{array}$ & $\begin{array}{c}1.089 \\
{[0.178]}\end{array}$ & $\begin{array}{c}1.079 \\
{[0.192]}\end{array}$ \\
\hline skilledbluecollar53 & & $\begin{array}{l}1.418^{* *} \\
{[0.183]}\end{array}$ & $\begin{array}{c}1.286 \\
{[0.176]}\end{array}$ & $\begin{array}{c}1.29 \\
{[0.177]}\end{array}$ & $\begin{array}{c}1.26 \\
{[0.173]}\end{array}$ & $\begin{array}{c}1.269 \\
{[0.175]}\end{array}$ & $\begin{array}{c}1.302 \\
{[0.197]}\end{array}$ \\
\hline Unskilledbluecollar53 & & $\begin{array}{l}1.518 * * \\
{[0.203]}\end{array}$ & $\begin{array}{c}1.284 \\
{[0.182]}\end{array}$ & $\begin{array}{c}1.276 \\
{[0.182]}\end{array}$ & $\begin{array}{c}1.229 \\
{[0.176]}\end{array}$ & $\begin{array}{c}1.249 \\
{[0.180]}\end{array}$ & $\begin{array}{c}1.255 \\
{[0.199]}\end{array}$ \\
\hline missing53type1 & & $\begin{array}{c}0.987 \\
{[0.946]}\end{array}$ & $\begin{array}{c}1.227 \\
{[1.376]}\end{array}$ & $\begin{array}{c}1.172 \\
{[1.354]}\end{array}$ & $\begin{array}{c}1.045 \\
{[1.135]}\end{array}$ & $\begin{array}{c}1.098 \\
{[1.193]}\end{array}$ & $\begin{array}{c}1.936 \\
{[2.370]}\end{array}$ \\
\hline missing53type 2 & & $\begin{array}{l}1.810 * * \\
{[0.308]}\end{array}$ & $\begin{array}{l}1.477 * \\
{[0.262]}\end{array}$ & $\begin{array}{l}1.491^{*} \\
{[0.265]}\end{array}$ & $\begin{array}{l}1.466^{*} \\
{[0.261]}\end{array}$ & $\begin{array}{l}1.511^{*} \\
{[0.271]}\end{array}$ & $\begin{array}{c}1.408 \\
{[0.278]}\end{array}$ \\
\hline \multicolumn{8}{|c|}{ Father's Social Class 1963} \\
\hline missing63type1 & & $\begin{array}{l}1.667 * * \\
{[0.291]}\end{array}$ & $\begin{array}{c}1.224 \\
{[0.224]}\end{array}$ & $\begin{array}{c}1.081 \\
{[0.202]}\end{array}$ & $\begin{array}{c}0.981 \\
{[0.187]}\end{array}$ & $\begin{array}{c}0.956 \\
{[0.182]}\end{array}$ & $\begin{array}{c}1.003 \\
{[0.208]}\end{array}$ \\
\hline lowerwhitecollar63 & & $\begin{array}{c}1.035 \\
{[0.114]}\end{array}$ & $\begin{array}{c}0.937 \\
{[0.109]}\end{array}$ & $\begin{array}{c}0.934 \\
{[0.108]}\end{array}$ & $\begin{array}{c}0.93 \\
{[0.108]}\end{array}$ & $\begin{array}{c}0.929 \\
{[0.108]}\end{array}$ & $\begin{array}{c}1.011 \\
{[0.131]}\end{array}$ \\
\hline lowerentrepreneur63 & & $\begin{array}{c}1.224 \\
{[0.176]}\end{array}$ & $\begin{array}{c}1.078 \\
{[0.163]}\end{array}$ & $\begin{array}{c}1.08 \\
{[0.163]}\end{array}$ & $\begin{array}{c}1.089 \\
{[0.165]}\end{array}$ & $\begin{array}{c}1.068 \\
{[0.163]}\end{array}$ & $\begin{array}{c}1.167 \\
{[0.196]}\end{array}$ \\
\hline skilledbluecollar63 & & $\begin{array}{c}1.223 \\
{[0.156]}\end{array}$ & $\begin{array}{c}1.01 \\
{[0.134]}\end{array}$ & $\begin{array}{c}0.988 \\
{[0.131]}\end{array}$ & $\begin{array}{c}0.975 \\
{[0.129]}\end{array}$ & $\begin{array}{c}0.983 \\
{[0.131]}\end{array}$ & $\begin{array}{c}1.053 \\
{[0.155]}\end{array}$ \\
\hline unskilledbluecollar63 & & $\begin{array}{l}1.474 * * \\
{[0.194]}\end{array}$ & $\begin{array}{c}1.123 \\
{[0.153]}\end{array}$ & $\begin{array}{c}1.079 \\
{[0.147]}\end{array}$ & $\begin{array}{c}1.053 \\
{[0.144]}\end{array}$ & $\begin{array}{c}1.059 \\
{[0.146]}\end{array}$ & $\begin{array}{c}1.189 \\
{[0.181]}\end{array}$ \\
\hline \multicolumn{8}{|l|}{ Other Measures of SES } \\
\hline Swedish & & $\begin{array}{c}1.141 \\
{[0.160]}\end{array}$ & $\begin{array}{c}1.257 \\
{[0.184]}\end{array}$ & $\begin{array}{c}1.283 \\
{[0.189]}\end{array}$ & $\begin{array}{c}1.274 \\
{[0.188]}\end{array}$ & $\begin{array}{c}1.252 \\
{[0.188]}\end{array}$ & $\begin{array}{c}1.28 \\
{[0.208]}\end{array}$ \\
\hline employhh60 & & $\begin{array}{c}0.909 \\
{[0.078]}\end{array}$ & $\begin{array}{c}0.936 \\
{[0.084]}\end{array}$ & $\begin{array}{c}1.01 \\
{[0.092]}\end{array}$ & $\begin{array}{c}1.055 \\
{[0.097]}\end{array}$ & $\begin{array}{c}1.047 \\
{[0.097]}\end{array}$ & $\begin{array}{c}1.046 \\
{[0.105]}\end{array}$ \\
\hline dadincome63 & & $\begin{array}{c}0.996 \\
{[0.002]}\end{array}$ & $\begin{array}{c}0.998 \\
{[0.002]}\end{array}$ & $\begin{array}{c}0.998 \\
{[0.002]}\end{array}$ & $\begin{array}{c}0.999 \\
{[0.002]}\end{array}$ & $\begin{array}{c}0.998 \\
{[0.002]}\end{array}$ & $\begin{array}{c}0.999 \\
{[0.002]}\end{array}$ \\
\hline fathereducation 3 & & $\begin{array}{c}0.739 * * \\
{[0.065]}\end{array}$ & $\begin{array}{c}0.849 \\
{[0.077]}\end{array}$ & $\begin{array}{c}0.854 \\
{[0.078]}\end{array}$ & $\begin{array}{c}0.874 \\
{[0.080]}\end{array}$ & $\begin{array}{c}0.868 \\
{[0.079]}\end{array}$ & $\begin{array}{c}0.866 \\
{[0.086]}\end{array}$ \\
\hline fathereducation 4 & & $\begin{array}{c}0.81 \\
{[0.119]}\end{array}$ & $\begin{array}{c}0.949 \\
{[0.145]}\end{array}$ & $\begin{array}{c}0.943 \\
{[0.144]}\end{array}$ & $\begin{array}{c}0.951 \\
{[0.144]}\end{array}$ & $\begin{array}{c}0.958 \\
{[0.146]}\end{array}$ & $\begin{array}{c}0.996 \\
{[0.166]}\end{array}$ \\
\hline mothereducation 3 & & $\begin{array}{c}0.786 \\
{[0.114]}\end{array}$ & $\begin{array}{c}0.928 \\
{[0.143]}\end{array}$ & $\begin{array}{c}0.937 \\
{[0.144]}\end{array}$ & $\begin{array}{c}0.941 \\
{[0.145]}\end{array}$ & $\begin{array}{c}0.928 \\
{[0.143]}\end{array}$ & $\begin{array}{c}0.906 \\
{[0.151]}\end{array}$ \\
\hline mothereducation 4 & & $\begin{array}{c}0.883 \\
{[0.209]}\end{array}$ & $\begin{array}{c}1.075 \\
{[0.268]}\end{array}$ & $\begin{array}{c}1.086 \\
{[0.270]}\end{array}$ & $\begin{array}{c}1.081 \\
{[0.267]}\end{array}$ & $\begin{array}{c}1.039 \\
{[0.260]}\end{array}$ & $\begin{array}{c}1.038 \\
{[0.273]}\end{array}$ \\
\hline \multicolumn{8}{|c|}{ Cognitive and Non-Cognitive Ability } \\
\hline Verbal ( $6^{\text {th }}$ grade test $)$ & & & $\begin{array}{c}0.995 \\
{[0.006]}\end{array}$ & $\begin{array}{c}0.996 \\
{[0.006]}\end{array}$ & $\begin{array}{c}0.997 \\
{[0.006]}\end{array}$ & $\begin{array}{c}0.992 \\
{[0.006]}\end{array}$ & $\begin{array}{c}0.992 \\
{[0.006]}\end{array}$ \\
\hline
\end{tabular}


Spatial ( $6^{\text {th }}$ grade test $)$

Math $\left(6^{\text {th }}\right.$ grade test $)$

grade6marks

Dinstructions (draft)

Dverbal (draft)

Dspatial (draft)

Dtechnical (draft)

Dpsychological (draft)

Household Instability

Alcoholic Parent:53-72

Father Drunkenness: 53-72

Mother Drunkennes:53-72

Parental Mental Illness:53-72

Father Died 53-72

Mother Died 53-72

Any social support: 53-72

Years of support: 53-72

Attitudes

School Absence when not sick?

Smoke in School?

$\begin{array}{ccccc}0.996 & 0.996 & 0.996 & 0.997 & 0.999 \\ {[0.005]} & {[0.005]} & {[0.005]} & {[0.005]} & {[0.005]} \\ 1.003 & 1.003 & 1.004 & 1.004 & 1.004 \\ {[0.005]} & {[0.005]} & {[0.005]} & {[0.005]} & {[0.005]} \\ 0.994 * * & 0.994 * * & 0.994 * * & 0.995 * * & 0.994 * * \\ {[0.001]} & {[0.001]} & {[0.001]} & {[0.001]} & {[0.001]}\end{array}$

$\begin{array}{lllll}0.964 & 0.965 & 0.968 & 0.97 & 0.964\end{array}$

$\left[\begin{array}{lllll}0.024 & {[0.024]} & {[0.025]} & {[0.025]} & {[0.026]}\end{array}\right.$

$\begin{array}{lllll}0.950 * & 0.949 * & 0.949 * & 0.948 * & 0.938 * *\end{array}$

$\left[\begin{array}{lllll}0.021] & {[0.021]} & {[0.021]} & {[0.022]} & {[0.023]}\end{array}\right.$

$\begin{array}{lllll}1.065 * * & 1.066 * * & 1.062 * * & 1.063 * * & 1.065 * *\end{array}$

$\left[\begin{array}{lllll}0.020] & {[0.021]} & {[0.021]} & {[0.021]} & {[0.022]}\end{array}\right.$

$\begin{array}{lllll}0.991 & 0.996 & 0.998 & 0.994 & 0.995\end{array}$

$\left[\begin{array}{lllll}0.018 & {[0.019]} & {[0.019]} & {[0.019]} & {[0.020]}\end{array}\right.$

$\begin{array}{lllll}0.852 * * & 0.856 * * & 0.859 * * & 0.866 * * & 0.864 * *\end{array}$

$\left[\begin{array}{llllll}0.013 & {[0.013]} & {[0.013]} & {[0.013]} & {[0.014]}\end{array}\right.$

$1.567 * * \quad 1.340 * \quad 1.318 * \quad 1.421 *$

$[0.195] \quad[0.175] \quad[0.171] \quad[0.200]$

$1.477 * \quad 1.408 * \quad 1.379 * \quad 1.297$

$[0.235] \quad[0.227] \quad[0.223] \quad[0.234]$

$\begin{array}{llll}2.928 & 2.828 & 2.804 & 2.682\end{array}$

$[1.696] \quad[1.604] \quad[1.604] \quad[1.684]$

$\begin{array}{llll}1.387 * * & 1.143 & 1.137 & 1.097\end{array}$

$[0.141] \quad[0.124] \quad[0.123] \quad[0.128]$

$1.987 * * \quad 1.881 * * \quad 1.867 * * \quad 1.830 * *$

$[0.371] \quad[0.360] \quad[0.357] \quad[0.375]$

$1.818 * \quad 1.617 \quad 1.504 \quad 1.351$

$[0.511] \quad[0.465] \quad[0.438] \quad[0.408]$

$1.292 * * \quad 1.287 * * \quad 1.269 *$

[0.112] [0.112] [0.121]

$1.028 * 1.028 * \quad 1.030 *$

[0.014] [0.014] [0.015]

$189 * * \quad 1.239 * *$

[0.074] [0.083]

$1.583 * * \quad 1.655 * *$

[0.101] [0.115]

\begin{tabular}{lccccccc}
\hline Neighborhood Fixed Effects & NO & NO & NO & NO & NO & NO & YES \\
\hline Observations & 7719 & 7719 & 7719 & 7719 & 7719 & 7719 & 7335
\end{tabular}

Standard errors in parentheses. * significant at 5\%; ** significant at $1 \%$. Estimates a logit regression and reports odds ratios. Missing observations are replaced with the variable mean and dummy variables indicating that the observations are missing are included but not presented in the above table. Note that the sample size decreases when neighborhood fixed effects are included because some neighborhoods have so few people included that the neighborhood is a perfect predictor of cohort member criminality; these individuals get dropped from the analysis. 